\title{
Exertional ventilation/carbon dioxide output relationship in COPD: from physiological mechanisms to clinical applications
}

\author{
J. Alberto Neder $\mathbb{1}^{1}$, Danilo C. Berton $\mathbb{1}^{1,2}$, Devin B. Phillips ${ }^{1}$ and Denis E. O’Donnell $\mathbb{\mathbb { D }}^{1}$
}

\author{
Number 8 in the Series "Ventilatory efficiency and its clinical prognostic value in cardiorespiratory \\ disorders" \\ Edited by Pierantonio Laveneziana and Paolo Palange
}

${ }^{1}$ Respiratory Investigation Unit and Laboratory of Clinical Exercise Physiology, Queen's University and Kingston General Hospital, Kingston, ON, Canada. ${ }^{2}$ Division of Respiratory Medicine, Federal University of Rio Grande do Sul, Porto Alegre, Brazil.

Corresponding author: J. Alberto Neder (alberto.neder@queensu.ca)

Shareable abstract (@ERSpublications)

The minute ventilation/carbon dioxide production relationship is relevant to a number of patientrelated outcomes in COPD. Minute ventilation/carbon dioxide production, therefore, should be valued in the clinical management of these patients. https://bit.ly/3df $2 \mathrm{upH}$

Cite this article as: Neder JA, Berton DC, Phillips DB, et al. Exertional ventilation/carbon dioxide output relationship in COPD: from physiological mechanisms to clinical applications. Eur Respir Rev 2021; 30: 200190 [DOI: 10.1183/16000617.0190-2020].

Copyright @ERS 2021

This version is distributed unde the terms of the Creative Commons Attribution Non-Commercial Licence 4.0. For commercial reproduction rights and permissions contact permissions@ersnet.org

This article has supplementary material available from err.ersjournals.com

Received: 18 June 2020 Accepted: 30 Sept 2020

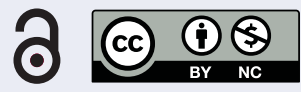

\section{Abstract}

There is well established evidence that the minute ventilation $\left(V_{\mathrm{E}}^{\prime}\right) /$ carbon dioxide output $\left(V^{\prime} \mathrm{CO}_{2}\right)$ relationship is relevant to a number of patient-related outcomes in COPD. In most circumstances, an increased $V^{\prime}{ }_{\mathrm{E}} / V^{\prime} \mathrm{CO}_{2}$ reflects an enlarged physiological dead space ("wasted” ventilation), although alveolar hyperventilation (largely due to increased chemosensitivity) may play an adjunct role, particularly in patients with coexistent cardiovascular disease. The $V_{E}^{\prime} / V^{\prime} \mathrm{CO}_{2}$ nadir, in particular, has been found to be an important predictor of dyspnoea and poor exercise tolerance, even in patients with largely preserved forced expiratory volume in $1 \mathrm{~s}$. As the disease progresses, a high nadir might help to unravel the cause of disproportionate breathlessness. When analysed in association with measurements of dynamic inspiratory constraints, a high $V_{\mathrm{E}}^{\prime} / V^{\prime} \mathrm{CO}_{2}$ is valuable to ascertain a role for the "lungs" in limiting dyspnoeic patients. Regardless of disease severity, cardiocirculatory (heart failure and pulmonary hypertension) and respiratory (lung fibrosis) comorbidities can further increase $V_{E}^{\prime} / V_{\mathrm{CO}_{2}}^{\prime}$. A high $V_{E}^{\prime} / V_{\mathrm{CO}_{2}}^{\prime}$ is a predictor of poor outcome in lung resection surgery, adding value to resting lung hyperinflation in predicting all-cause and respiratory mortality across the spectrum of disease severity. Considering its potential usefulness, the $V_{\mathrm{E}}^{\prime} / V^{\prime} \mathrm{CO}_{2}$ should be valued in the clinical management of patients with COPD.

\section{Introduction}

It has been well established that changes in minute ventilation $\left(V_{\mathrm{E}}^{\prime}\right)$ are tightly coupled to the rate at which metabolically produced carbon dioxide $\left(\mathrm{CO}_{2}\right)$ is released by the lungs during exercise $\left(V^{\prime} \mathrm{CO}_{2}\right.$, i.e. venous return $\times$ mixed-venous $\mathrm{CO}_{2}$ content) [1,2]. The submaximal ventilatory demands are particularly relevant to set the limits of exercise tolerance in patients with reduced ventilatory capacity, e.g. those suffering from COPD [3, 4]. In fact, relatively minor increases in the $V_{E}^{\prime} / V^{\prime} \mathrm{CO}_{2}$ relationship are expected to have a large impact on the rate at which $V^{\prime}$ E reaches a relatively-fixed "ceiling” (as roughly estimated by the maximal breathing capacity, for example (supplementary figure S1) [5].

As discussed elsewhere in this series, the $V_{\mathrm{E}}^{\prime}$ required to wash out a given rate of $V^{\prime} \mathrm{CO}_{2}$ is inversely related to the arterial partial pressure for $\mathrm{CO}_{2}\left(P_{\mathrm{aCO}}\right)$ (since more alveolar ventilation is needed to maintain the $P_{\mathrm{aCO}}$ at a low compared to a high value), and positive related to the fraction of tidal volume $\left(V_{\mathrm{T}}\right)$ "wasted" in the dead space $\left(V_{\mathrm{D}}\right)$, i.e. the higher the physiological (phys) $V_{\mathrm{D}} / V_{\mathrm{T}}$ [1]. Since the $P_{\mathrm{aCO}}$ is maintained relatively constant as $V_{\mathrm{CO}_{2}}^{\prime}$ increases (at least during moderate exercise) (supplementary figure S2c) [1], the 
hyperbolic decrease in $V_{\mathrm{D}} / V_{\text {Tphys }}$ (supplementary figure S2a) is accompanied by a similar decrease in the $V^{\prime}{ }_{\mathrm{E}} / V^{\prime} \mathrm{CO}_{2}$ ratio towards a minimum value ("nadir") (supplementary figure $\mathrm{S} 2 \mathrm{~b}$ ) [6]. Thus, when $V_{\mathrm{E}}^{\prime}$ is plotted as a function of $V^{\prime} \mathrm{CO}_{2}$ during an incremental cardiopulmonary exercise test, a linear relationship with a positive y-intercept emerges (supplementary figure S2d). In this context, increases in the intercept and/or in the slope can lead to a high $V_{\mathrm{E}}^{\prime} / V^{\prime} \mathrm{CO}_{2}$ nadir [7]. From a physiological standpoint, the higher the $V_{\mathrm{D}} / V_{\text {Tphys }}$ and the lower the $P_{\mathrm{aCO}_{2}}$ set-point, the higher the $V^{\prime}{ }_{\mathrm{E}} / V^{\prime} \mathrm{CO}_{2}$ nadir [2]. The $V_{\mathrm{D}} / V_{\mathrm{Tphys}}$ is the lowest at the $V_{\mathrm{E}}^{\prime} / V^{\prime} \mathrm{CO}_{2}$ nadir (supplementary figure S2a and b), allowing a more accurate estimation of the wasted ventilation. Moreover, the $V^{\prime}{ }_{\mathrm{E}} / V^{\prime} \mathrm{CO}_{2}$ nadir has been found to be highly reproducible in normal subjects [8] and in patients with COPD [9].

In the present review we update and expand a previous review on the $V^{\prime}{ }_{\mathrm{E}} / V^{\prime} \mathrm{CO}_{2}$ relationship published in 2017 in the European Respiratory Journal [10]. Although a high $V_{\mathrm{E}}^{\prime} / V^{\prime} \mathrm{CO}_{2}$ has been widely termed "ventilatory inefficiency" or "excess ventilation" [11-14], we avoid this terminology herein, because, as discussed below, substantial inefficiency (i.e. increased wasted $V_{\mathrm{E}}^{\prime}$ ) may coexist with a relatively preserved, or even reduced, $V_{\mathrm{E}}^{\prime} / V^{\prime} \mathrm{CO}_{2}$ in patients with COPD. After a concise overview on the structural and functional determinants of $V^{\prime}{ }_{E} / V^{\prime}{ }_{\mathrm{CO}_{2}}$ in COPD, we focus on its relevance to exertional dyspnoea and exercise tolerance, exploring the clinical scenarios in which the measurement may add to resting clinical assessment. Additionally, we provide evidence on how $V^{\prime}{ }_{E} / V_{\mathrm{CO}_{2}}^{\prime}$ may allow us to better judge the functional impact of comorbidities, assess future risk and prognosis, and determine the effects of selected therapeutic interventions on patients' exercise tolerance (table 1). Finally, we outline some key gaps in knowledge that might benefit from additional research (table 2).

Structural and functional determinants of $V^{\prime}{ }_{E} / V^{\prime} \mathrm{CO}_{2}$ in COPD

Several studies have shown that an increased $V_{\mathrm{D}} / V_{\text {Tphys }}$, partially due to emphysema [21, 23, 25, 28, 96, 97], constitutes an important correlate of a high $V_{\mathrm{E}}^{\prime} / V^{\prime} \mathrm{CO}_{2}$. As discussed later, this is particularly true in patients who are not severely compromised from the mechanical standpoint, i.e. those who are able to increase $V_{\mathrm{E}}^{\prime}$ in an attempt to overcome an increased alveolar $V_{\mathrm{D}}$. There is some limited evidence that the increased $V_{\mathrm{D}} / V_{\text {Tphys }}$ is more closely related to an enlarged alveolar $V_{\mathrm{D}}$ per se rather than a small $V_{\mathrm{T}}$ [20]. Additionally, external (series) $V_{\mathrm{D}}$ predictably increased $V_{\mathrm{E}}^{\prime} / V^{\prime} \mathrm{CO}_{2}$ [18]. As in many chronic pulmonary diseases, increased regional [98], and, in some patients, "mean” alveolar ventilation/perfusion $\left(V^{\prime} / Q^{\prime}\right)$ ratio heterogeneity and diffusion limitation [99] are probably related to a high $V_{\mathrm{D}} / V_{\text {Tphys }}$ in COPD [100].

Impaired pulmonary perfusion of non-emphysematous areas [101] may also contribute to high $V_{\mathrm{D}} / V_{\text {Tphys }}$ and $V_{\mathrm{E}}^{\prime} / V_{\mathrm{CO}_{2}}^{\prime}$ in a highly variable combination in subjects with similar forced expiratory volume in $1 \mathrm{~s}$ $\left(\mathrm{FEV}_{1}\right)[19,97]$. It is noteworthy that a low transfer factor of the lung for carbon monoxide $\left(T_{\mathrm{LCO}}\right)$, which is notoriously influenced by $V^{\prime} / Q^{\prime}$ abnormalities [102], has been inversely related to $V_{\mathrm{E}}^{\prime} / V_{\mathrm{CO}_{2}}^{\prime}$ in recent studies [22, 27]. Patients unable to expand gas exchange surface area (as assessed with $T_{\mathrm{LCO}}$ during exercise) relative to pulmonary blood flow showed a higher $V_{E}^{\prime} / V^{\prime} \mathrm{CO}_{2}$ and a lower exercise capacity [24]. In addition, patients with mild COPD and high $V^{\prime}{ }_{\mathrm{E}} / V^{\prime} \mathrm{CO}_{2}(\geqslant 34)$ had lower $T_{\mathrm{LCO}}$ and pulmonary capillary blood volume response to exercise [26]. It is conceivable that the cross-relationships among $V_{\mathrm{E}}^{\prime} / V^{\prime} \mathrm{CO}_{2}$, $V_{\mathrm{D}} / V_{\text {Tphys }}$ and $T_{\mathrm{LCO}}$ represent, in addition to emphysema, a complex combination of the effects of accelerated pulmonary vascular ageing in smokers [103], destruction/dysfunction of the alveolar-capillary bed [101], and, in some patients, hypoxic pulmonary vasoconstriction [104]. In any case, the pulmonary vascular abnormalities may progress to overt pulmonary hypertension in selected patients, an important cause of a high $V_{E}^{\prime} / V^{\prime} \mathrm{CO}_{2}$ (see the section on Impact of COPD comorbidities on $\mathrm{V}_{\mathrm{E}}^{\prime} / \mathrm{V}^{\prime} \mathrm{CO}_{2}$ ).

Alveolar hyperventilation is another potential cause of a high $V^{\prime}{ }_{E} / V^{\prime} \mathrm{CO}_{2}$ in $\mathrm{COPD}[1,2]$. A chronically low $P_{\mathrm{aCO}}$ (likely due to heightened chemostimulation) [105] may shift the level at which it is centrally regulated ("set-point") downward [106], in a vicious circle. The relative contribution of a low $P_{\mathrm{aCO}_{2}}$ to a high $V_{\mathrm{E}}^{\prime} / V^{\prime} \mathrm{CO}_{2}$ remains elusive, being probably more relevant in those with cardiocirculatory comorbidities (see the section on Impact of COPD comorbidities on $\mathrm{V}_{\mathrm{E}}^{\prime} / \mathrm{V}^{\prime} \mathrm{CO}_{2}$ ). For instance, ElbehaiRy et al. [20] found that $P_{\mathrm{aCO}_{2}}$ was inversely related to $V_{\mathrm{E}}^{\prime} / V^{\prime} \mathrm{CO}_{2}$, though to a lesser extent than $V_{\mathrm{D}} / V_{\mathrm{Tphys}}$, in a group of patients with preserved $\mathrm{FEV}_{1}$. Heightened stimulation of mechano- and metaboreceptors in the peripheral muscles (“ergoreceptors”) [83] may also contribute to alveolar hyperventilation in selected patients.

It should be noted that the contribution of alveolar hyperventilation to a high $V_{\mathrm{E}}^{\prime} / V^{\prime} \mathrm{CO}_{2}$ in $\mathrm{COPD}$ is likely to be overestimated if one considers the end-tidal partial pressure for $\mathrm{CO}_{2}\left(P_{\mathrm{ETCO}_{2}}\right)$ rather than the $P_{\mathrm{aCO}}$ [107]. This is the case because $V^{\prime} / Q^{\prime}$ abnormalities, specifically, alveolar $V_{\mathrm{D}}$, are known to decrease $P_{\mathrm{ETCO}_{2}}$ at a given $P_{\mathrm{aCO}_{2}}$ [108] (as the former is diluted in the $V_{\mathrm{D}} / V_{\text {Tphys}}$ ); an effect that increases as exercise intensifies [20]. The topic is further complicated by the fact that $V_{\mathrm{D}} / V_{\text {Tphys }}$ and $P_{\mathrm{aCO}_{2}}$ are not 
TABLE 1 Overview of cardiopulmonary exercise testing-based studies on the minute ventilation $\left(V_{E}^{\prime}\right) /$ carbon dioxide output $\left(V^{\prime} \mathrm{CO}_{2}\right)$ relationship in different clinical scenarios in COPD

$\begin{array}{clc}\text { Subjects } & \text { Disease } & \text { Main result } \\ \mathrm{n} & \text { severity }\end{array}$

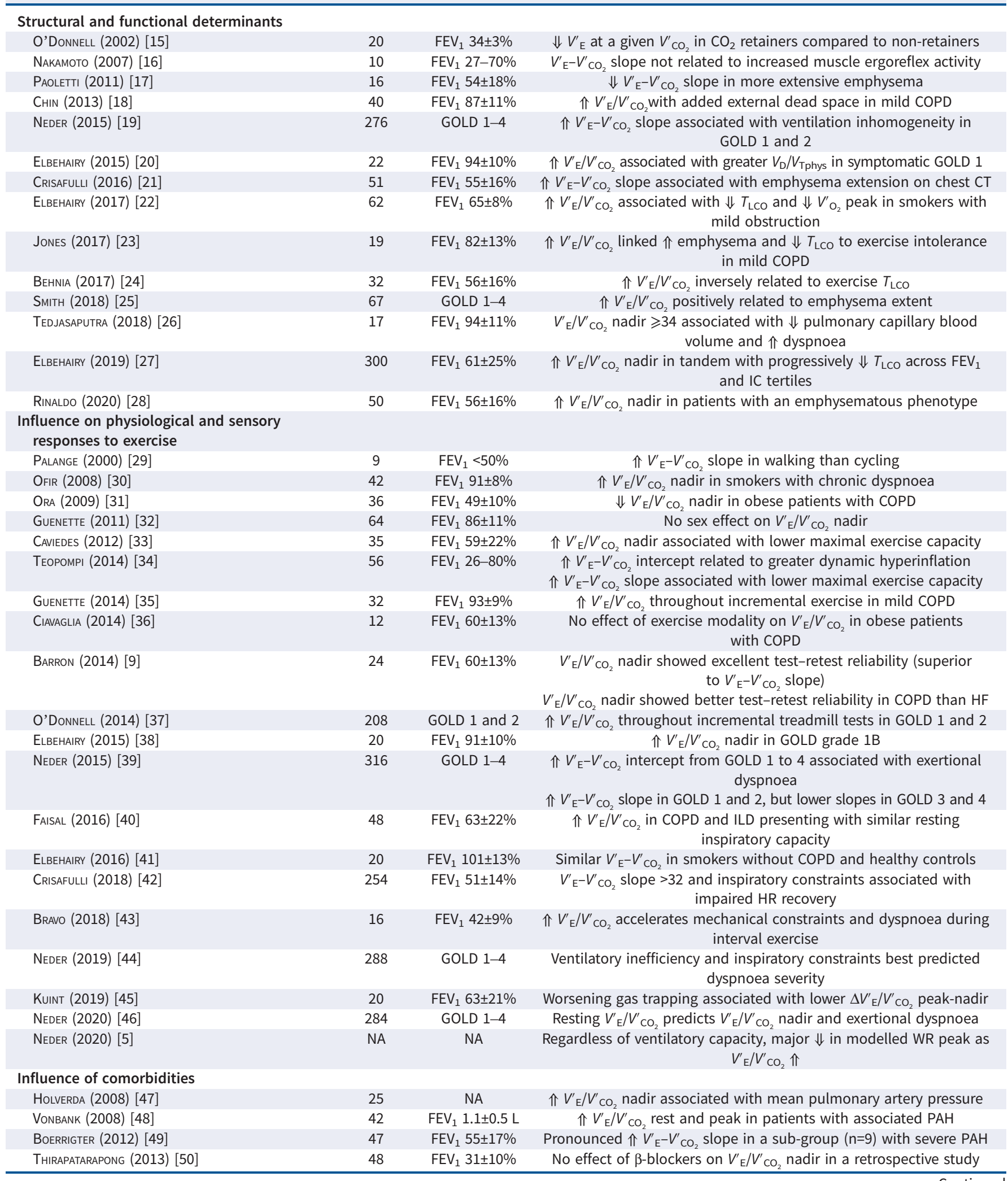


TABLE 1 Continued

$\begin{array}{clc}\text { Subjects } & \text { Disease } & \text { Main result } \\ \mathbf{n} & \text { severity } & \end{array}$

\begin{tabular}{|c|c|c|c|}
\hline THIRAPATARAPONG (2014) [51] & 98 & $\mathrm{FEV}_{1} 20 \pm 7 \%$ & $\begin{array}{c}\text { No association of } V_{E}^{\prime} / V^{\prime} \mathrm{CO}_{2} \text { peak with PAH in severe to very severe } \\
\text { COPD }\end{array}$ \\
\hline TEOPOMPI (2014) [52] & 46 & $\mathrm{FEV}_{1} 52 \pm 16 \%$ & $\begin{array}{l}\Downarrow V_{\mathrm{E}}^{\prime}-V_{\mathrm{CO}_{2}}^{\prime} \text { slope in COPD compared to } \mathrm{HF} \text { in patients with poorer } \\
\text { exercise capacity } \\
\Uparrow V_{\mathrm{E}^{\prime}-V^{\prime} \mathrm{CO}_{2} \text { intercept in COPD compared to HF }}^{\prime}\end{array}$ \\
\hline ThiRAPATARAPONG (2014) [53] & 108 & $\mathrm{FEV}_{1} 26 \pm 14 \%$ & $\Uparrow V^{\prime} / V^{\prime} \mathrm{CO}_{2}$ nadir in COPD patients with coexistent coronary artery \\
\hline ApostoLo (2015) [54] & 95 & $\mathrm{FEV}_{1} 53 \pm 13 \%$ & $\Uparrow V^{\prime}{ }_{\mathrm{E}}-V^{\prime} \mathrm{CO}_{2}$ intercept in COPD and COPD-HF compared to $\mathrm{HF}$ \\
\hline ARBEX (2016) [55] & 98 & $\mathrm{FEV}_{1} 55 \pm 17 \%$ & 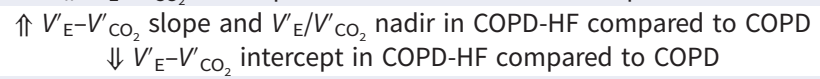 \\
\hline Rосна (2016) [56] & 68 & $\mathrm{FEV}_{1} 60 \pm 18 \%$ & $\Uparrow V_{\mathrm{E}}^{\prime}-V_{\mathrm{CO}_{2}}^{\prime}$ slope in COPD-HF with exercise oscillatory ventilation \\
\hline Rосна (2017) [57] & 22 & $\mathrm{FEV}_{1} 60 \pm 11 \%$ & $\begin{array}{c}\Uparrow V_{\mathrm{E}}^{\prime} / V^{\prime} \mathrm{CO}_{2} \text { more associated with hyperventilation than } \Uparrow V_{\mathrm{D}} / V_{\mathrm{Tphys}} \text { in } \\
\text { COPD-HF }\end{array}$ \\
\hline MULLER (2018) [58] & 40 & $\mathrm{FEV}_{1} 43 \pm 13 \%$ & $V_{E}^{\prime} / V^{\prime} \mathrm{CO}_{2}$ not related to diastolic dysfunction \\
\hline Cherneva (2019) [59] & 104 & $\mathrm{FEV}_{1} 1.4 \pm 0.4 \mathrm{~L}$ & $\begin{array}{c}\Uparrow V_{E}^{\prime}-V^{\prime} \mathrm{CO}_{2} \text { slope associated with stress-induced diastolic } \\
\text { dysfunction }\end{array}$ \\
\hline Sмітн (2019) [60] & 22 & $\mathrm{FEV}_{1} 60 \pm 11 \%$ & $\begin{array}{c}\Uparrow V_{E^{-}}^{\prime} V_{\mathrm{CO}_{2}}^{\prime} \text { intercept in COPD compared to } \mathrm{HF} \text { with preserved and } \\
\text { low ejection fraction }\end{array}$ \\
\hline GoulART (2020) [61] & 10 & $\mathrm{FEV}_{1} 1.6 \pm 0.1 \mathrm{~L}$ & $\Uparrow V_{E^{\prime}}^{\prime} V_{\mathrm{CO}_{2}}^{\prime}$ slope associated with disease severity in COPD-HF \\
\hline Costa (2020) [62] & 42 & $\mathrm{FEV}_{1} 52 \pm 14 \%$ & $\begin{array}{c}\Uparrow V_{E}^{\prime \prime} / V^{\prime} \mathrm{CO}_{2} \text { was a key correlate of dyspnoea and exercise intolerance } \\
\text { in CPFE }\end{array}$ \\
\hline PLACHI (2020) [63] & 28 & NA & $\begin{array}{c}\text { Mechanical constraints modulate dyspnoea- } V_{E}^{\prime} \text { differently in COPD } \\
\text { and } \mathrm{HF}\end{array}$ \\
\hline \multicolumn{4}{|l|}{ Risk assessment/prognosis } \\
\hline TORCHIO (2010) [64] & 145 & $\mathrm{FEV}_{1} 73 \pm 16 \%$ & $\Uparrow V^{\prime}{ }^{\prime}-V^{\prime} \mathrm{CO}_{2}$ slope predicted mortality after lung resection surgery \\
\hline BRUnelLi (2012) [65] & 70 & $\mathrm{FEV}_{1} 81 \pm 18 \%$ & $\begin{array}{c}V_{E^{-}}^{\prime} V^{\prime} \mathrm{CO}_{2} \text { slope }>35 \text { predicted poor outcome after lung } \\
\text { resection surgery }\end{array}$ \\
\hline SHAFIEK (2016) [66] & 55 & $\mathrm{FEV}_{1} 60 \pm 17 \%$ & $\begin{array}{c}V_{E^{-}}^{\prime}-V^{\prime} \mathrm{CO}_{2} \text { slope }>35 \text { predicted poor outcome after lung } \\
\text { resection surgery }\end{array}$ \\
\hline NedeR (2016) [67] & 288 & $\mathrm{FEV}_{1} 18-148 \%$ & $\begin{array}{c}V_{\mathrm{E}}^{\prime} / V^{\prime} \mathrm{CO}_{2} \text { nadir }>34 \text { added to resting hyperinflation to } \\
\text { predict mortality }\end{array}$ \\
\hline Alencar (2016) [68] & 30 & $\mathrm{FEV}_{1} 57 \pm 17 \%$ & $\begin{array}{l}V_{\mathrm{E}}^{\prime} / V^{\prime} \mathrm{CO}_{2} \text { nadir }>34 \text { and right ventricular function predicted mortality } \\
\text { in COPD-HF }\end{array}$ \\
\hline TORCHIO (2017) [69] & 263 & GOLD 1-4 & $\begin{array}{c}\Uparrow V^{\prime}{ }_{E}-V^{\prime} \mathrm{CO}_{2} \text { slope was the best predictor of death after } \\
\text { pneumonectomy }\end{array}$ \\
\hline MIYAZAKI (2018) [70] & 974 & $\mathrm{FEV}_{1} 78 \pm 23 \%$ & $\begin{array}{c}V_{\mathrm{E}}^{\prime}-V^{\prime} \mathrm{CO}_{2} \text { slope predicted } 90 \text {-day and 2-year survival after lung } \\
\text { resection for cancer }\end{array}$ \\
\hline ELLENBERGer (2018) [71] & 151 & $\mathrm{FEV}_{1} 82 \pm 21 \%$ & $\begin{array}{c}V_{\mathrm{E}}^{\prime} / V^{\prime} \mathrm{CO}_{2} \text { nadir }>40 \text { predicted 4-year survival after lung resection } \\
\text { for cancer }\end{array}$ \\
\hline CRISAFuLLI (2018) [42] & 254 & $\mathrm{FEV}_{1} 51 \pm 14 \%$ & $\Uparrow V^{\prime}-V_{\mathrm{CO}_{2}}^{\prime}$ slope associated with a delay in post-exercise heart rate \\
\hline \multicolumn{4}{|l|}{ Effects of interventions } \\
\hline Orens (1995) [72] & 5 & $\mathrm{FEV}_{1} 57 \pm 4 \%$ & Single lung $T x$ decreased $V_{E}^{\prime} / V^{\prime} \mathrm{CO}_{2}$ peak \\
\hline SOMfay (2001) [73] & 10 & $\mathrm{FEV}_{1} 31 \pm 10 \%$ & Decrements in $V_{E}^{\prime}$ with hyperoxia correlated with decreases in $V^{\prime} \mathrm{CO}_{2}$ \\
\hline O’Donnell (2001) [74] & 11 & $\mathrm{FEV}_{1} 31 \pm 3 \%$ & $\begin{array}{c}\text { Proportional decrements } V_{E}^{\prime} \text { and } V^{\prime}{ }_{\mathrm{CO}_{2}} \text { with hyperoxia in } \\
\text { advanced COPD }\end{array}$ \\
\hline O’DonnelL (2004) [75] & 23 & $\mathrm{FEV}_{1} 42 \pm 3 \%$ & $\begin{array}{c}\text { Salmeterol proportionally increased } V_{E}^{\prime} \text { and } V_{\mathrm{CO}_{2}}^{\prime} \text { during constant } \\
\text { work rate exercise }\end{array}$ \\
\hline Palange (2004) [76] & 12 & $\begin{array}{l}\mathrm{FEV}_{1}<50 \% \\
\text { pred }\end{array}$ & Heliox increased $V_{E}^{\prime} / V^{\prime} \mathrm{CO}_{2}$ during constant work rate exercise \\
\hline O’Donnell (2004) [77] & 187 & $\mathrm{FEV}_{1} 44 \pm 13 \%$ & $\begin{array}{c}\Uparrow V_{\mathrm{E}}^{\prime} \text { (due to higher } V_{\mathrm{T}} \text { ) at a given } V_{\mathrm{CO}_{2}}^{\prime} \text { with tiotropium compared to } \\
\text { placebo }\end{array}$ \\
\hline PoRszASz (2005) [78] & 24 & $\mathrm{FEV}_{1} 36 \pm 8 \%$ & $\begin{array}{c}\text { Exercise training proportionally reduced } V_{E}^{\prime} \text { and } V^{\prime} \mathrm{CO}_{2} \text { during } \\
\text { constant exercise }\end{array}$ \\
\hline Воввіо (2005) [79] & 11 & $\mathrm{FEV}_{1} 53 \pm 20 \%$ & Lobectomy increased $V^{\prime}{ }^{\prime}-V^{\prime} \mathrm{CO}_{2}$ slope \\
\hline Eves (2006) [80] & 10 & FEV $_{1} 47 \pm 17 \%$ & Normoxic heliox increased $V_{E}^{\prime} / V^{\prime} \mathrm{CO}_{2}$ more than hyperoxic heliox \\
\hline CHIAPPA (2009) [81] & 12 & $\mathrm{FEV}_{1} 45 \pm 13 \%$ & Heliox increased $V_{E}^{\prime} / V_{\mathrm{CO}_{2}}^{\prime}$ during constant work rate exercise \\
\hline HABEDANK (2011) [82] & 8 & NA & Bilateral lung $\mathrm{Tx}^{2}$ decreased $V_{\mathrm{E}}^{\prime}-V^{\prime} \mathrm{CO}_{2}$ slope \\
\hline GAGNON (2012) [83] & 8 & $\mathrm{FEV}_{1} 7 \pm 8 \%$ & $\begin{array}{c}\text { Spinal anesthesia reduced } V^{\prime}{ }_{E} / V_{\mathrm{CO}_{2}} \text { during constant work } \\
\text { rate exercise }\end{array}$ \\
\hline
\end{tabular}


TABLE 1 Continued

\begin{tabular}{|c|c|c|c|}
\hline & $\begin{array}{c}\text { Subjects } \\
n\end{array}$ & $\begin{array}{l}\text { Disease } \\
\text { severity }\end{array}$ & Main result \\
\hline KIM (2012) [84] & 1475 & $\mathrm{FEV}_{1}<45 \%$ & LVRS reduced $V_{\mathrm{E}}^{\prime} / V^{\prime} \mathrm{CO}_{2}$ during unloaded exercise \\
\hline Guenette (2013) [85] & 15 & $\mathrm{FEV}_{1} 86 \pm 15 \%$ & $\begin{array}{c}\Uparrow V_{E}^{\prime} / V_{\mathrm{CO}_{2}}^{\prime} \text { at isotime with fluticasone/salmeterol compared } \\
\text { to placebo }\end{array}$ \\
\hline QueIROGA (2013) [86] & 24 & $\mathrm{FEV}_{1} 35 \pm 10 \%$ & Heliox increased $V_{E}^{\prime} / V^{\prime} \mathrm{CO}_{2}$ during constant work rate exercise \\
\hline ARMStRong (2015) [87] & 55 & $\mathrm{FEV}_{1} 26 \pm 7 \%$ & LVRS reduced $V_{E}^{\prime} / V_{\mathrm{CO}_{2}}^{\prime}$ peak and nadir \\
\hline GLOECKL (2017) [88] & 10 & $\mathrm{FEV}_{1} 38 \pm 8 \%$ & $\begin{array}{l}\text { No effect of whole-body vibration training on } V^{\prime}{ }_{E} / V^{\prime} \mathrm{CO}_{2} \text { in } \\
\text { severe COPD }\end{array}$ \\
\hline LANGER (2018) [89] & 20 & $\mathrm{FEV}_{1} 47 \pm 19 \%$ & $\begin{array}{c}\text { No effect of inspiratory muscle training on } V_{E}^{\prime} / V^{\prime} \mathrm{CO}_{2} \text { during } \\
\text { constant-WR exercise }\end{array}$ \\
\hline O’Donnell (2018) [90] & 14 & $\mathrm{FEV}_{1} 62 \pm 10 \%$ & $\begin{array}{c}\text { No effect of dual bronchodilation on } V^{\prime}{ }_{E} / V^{\prime} \mathrm{CO}_{2} \text { during } \\
\text { constant-WR exercise }\end{array}$ \\
\hline BEHNIA (2018) [91] & 25 & $\mathrm{FEV}_{1} 1.5 \pm 0.6 \mathrm{~L}$ & No effect of dietary nitrate supplementation on $V_{E}^{\prime} / V_{\mathrm{CO}_{2}}^{\prime}$ nadir \\
\hline ElBeHAiRY (2018) [92] & 20 & FEV $_{1} 50 \pm 15 \%$ & No effect of acute bronchodilation on $V_{\mathrm{D}} / V_{\mathrm{T}}$ and $V_{\mathrm{E}}^{\prime} / V^{\prime} \mathrm{CO}_{2}$ \\
\hline PERROTTA (2019) [93] & 25 & $\mathrm{FEV}_{1} 61 \pm 22 \%$ & $\begin{array}{c}\Downarrow V^{\prime}{ }_{E}-V_{\mathrm{CO}_{2}}^{\prime} \text { slope and } \Uparrow \text { peak } V_{\mathrm{O}_{2}}^{\prime} \text { after high-intensity } \\
\text { exercise training }\end{array}$ \\
\hline GRAVIER (2019) [94] & 50 & $\mathrm{FEV}_{1} 62 \pm 19 \%$ & $\begin{array}{c}\text { No effect of pulmonary rehabilitation on lung cancer patients } \\
\text { undergoing PR }\end{array}$ \\
\hline HASLER (2020) [95] & 20 & $\mathrm{FEV}_{1} 64 \pm 19 \%$ & $\begin{array}{c}\Downarrow V^{\prime}{ }_{E} / V^{\prime} \mathrm{CO}_{2} \text { and } \Uparrow \text { WR peak with supplemental } \mathrm{O}_{2} \text { in } \\
\text { non-hypoxaemic patients }\end{array}$ \\
\hline \multicolumn{4}{|c|}{$\begin{array}{l}\Downarrow: \text { decreased; } \Uparrow: \text { increased; } \mathrm{FEV}_{1} \text { : forced expiratory volume in } 1 \mathrm{~s} ; \mathrm{CO}_{2}: \text { carbon dioxide; GOLD: Global Initiative for Chronic Obstructive Lung Disease; } \\
V_{\mathrm{D}} / V_{\mathrm{Tphys}}: \text { physiological dead space; CT: computed tomography; } T_{\mathrm{LCO}} \text { : transfer factor of the lung for carbon monoxide; } V_{\mathrm{O}_{2}}: \text { oxygen uptake; IC: } \\
\text { inspiratory capacity; HF: heart failure; ILD: interstitial lung disease; NA: not available/not applicable; WR: work rate; PAH: pulmonary arterial } \\
\text { hypertension; CPFE: combined pulmonary fibrosis and emphysema; Tx: transplant; LVRS: lung volume reduction surgery; PR: pulmonary } \\
\text { rehabilitation; } \mathrm{O}_{2} \text { : oxygen; } V_{\mathrm{T}} \text { : tidal volume; HR: heart rate. }\end{array}$} \\
\hline
\end{tabular}

independent variables. For instance, the extent to which the mean alveolar $\mathrm{CO}_{2}$ tension decreases in response to hyperventilation (high overall ratio alveolar $V^{\prime} / Q^{\prime}$ ) is underestimated by $P_{\mathrm{aCO}_{2}}$, thereby artificially increasing $V_{\mathrm{D}} / V_{\text {Tphys }}$ as measured by the Bohr-Enghoff method [109, 110]. Moreover, larger fluctuations in end-capillary $\mathrm{CO}_{2}$ pressure due to a high $V_{\mathrm{D}} / V_{\text {Tphys }}$ may overstimulate the peripheral and central chemoreceptors, leading to a low $P_{\mathrm{aCO}_{2}}[111]$.

It remains unclear whether the $V_{\mathrm{E}}^{\prime}-V_{\mathrm{CO}_{2}}^{\prime}$ slope and the $V_{\mathrm{E}}^{\prime}$ intercept have specific structural and physiological determinants in COPD. The addition of external $V_{\mathrm{D}}$ had a more discernible effect on the $V_{\mathrm{E}}^{\prime}$ intercept than the $V^{\prime}{ }_{\mathrm{E}}-V^{\prime} \mathrm{CO}_{2}$ slope both in health [110, 112, 113] and mild COPD [18]. However, a high intercept may merely reflect the expected effect of shallow slope (secondary to worsening mechanical constraints; figure 1), independent of the $V_{\mathrm{D}}$ [39, 114]. In individual cases, there is some disconnection between the directional changes of slope and intercept, suggesting that they may provide additive information [39, 54]. As outlined in table 2, relating $V_{\mathrm{E}}^{\prime}-V^{\prime} \mathrm{CO}_{2}$ slope and $V_{\mathrm{E}}^{\prime}$ intercept to structural abnormalities (emphysema burden, microvascular abnormalities, small airways disease) and $\mathrm{CO}_{2}$ chemosensitivity might shed new light on this topic.

Influence of $V^{\prime}{ }_{\mathrm{E}} / V^{\prime}{ }_{\mathrm{CO}_{2}}$ on the physiological and sensory responses to exercise in COPD A substantial body of evidence has been accumulated pointing out abnormalities in the $V_{\mathrm{E}}^{\prime} / V^{\prime} \mathrm{CO}_{2}$ relationship across the spectrum of COPD severity (table 1 ). In particular, a high $V_{\mathrm{E}}^{\prime} / V^{\prime} \mathrm{CO}_{2}$ has been consistently found in dyspnoeic patients with preserved or only mildly reduced $\mathrm{FEV}_{1}$ (supplementary figure S3) [18, 20, 35, 37-39, 115]. A high $V_{\mathrm{E}}^{\prime} / V^{\prime} \mathrm{CO}_{2}$ nadir in flow-limited patients accelerates the rate of dynamic lung hyperinflation and earlier attainment of critical dynamic inspiratory constraints [116]. In fact, the rate of decline of the dynamic inspiratory reserve volume to its minimal value is superior to conventional "breathing reserve" at peak exercise in the assessment of exertional dyspnoea in mild to advanced COPD [44] (figure 2). Patients showing a high $V_{E}^{\prime} / V^{\prime} \mathrm{CO}_{2}$ also showed a low tolerance to short bursts of high-intensity interval exercise, an exercise modality which is associated with more preserved breathing reserve [43]. Interestingly, a recent study found that even a high resting $V_{\mathrm{E}}^{\prime} / V^{\prime} \mathrm{CO}_{2}$, if associated with a low inspiratory capacity, predicts the burden of exertional dyspnoea in patients with COPD [46]. Therefore, a high $V_{\mathrm{E}}^{\prime} / V^{\prime} \mathrm{CO}_{2}$ and the dynamic inspiratory constraints, are jointly relevant to explain increased exertional dyspnoea and poor exercise capacity in COPD compared with age-matched healthy 
TABLE 2 Key unanswered questions on the mechanisms and consequences of minute ventilation $\left(V_{E}^{\prime}\right) /$ carbon dioxide output $\left(\mathrm{V}^{\prime} \mathrm{CO}_{2}\right)$ abnormalities in COPD

Exercise intolerance

comorbidities

Risk assessment/ prognosis
What are the structural determinants of increased $V_{D} / V_{\text {Tphys }}$ in milder disease?

What is the relevance of alveolar hyperventilation to increase $V_{E}^{\prime} / V^{\prime} \mathrm{CO}_{2}$ ? Does it change with disease severity?

What is the physiological meaning (if any) of the $V^{\prime}{ }_{E}^{-} V^{\prime} \mathrm{CO}_{2}$ intercept?

Is the $V^{\prime}{ }_{E} / V^{\prime}{ }_{\mathrm{CO}_{2}}$ consistently associated with specific disease phenotypes? How does very severe, end-stage disease influence $V^{\prime}{ }_{\mathrm{E}} / V^{\prime} \mathrm{CO}_{2}$ ?

Is resting $V^{\prime}{ }_{E} / V^{\prime} \mathrm{CO}_{2}$ useful to predict exercise intolerance and dyspnoea in patients unable to exercise?

Do emphysema severity and COPD phenotype influence $V^{\prime}{ }_{E} / V^{\prime}{ }_{\mathrm{CO}_{2}}$ in COPD-HF? Do $\mathrm{HF}$ aetiology and $\mathrm{HF}$ with preserved ejection fraction influence $V_{\mathrm{E}}^{\prime} / V^{\prime} \mathrm{CO}_{2}$ in COPD-HF?

What is the effect of exertional hypoxia on $V^{\prime}{ }_{E} / V^{\prime} \mathrm{CO}_{2}$ in hypoxaemic patients with COPD-HF?

Does $V^{\prime}{ }_{E} / V^{\prime} \mathrm{CO}_{2}$ relate to right ventricular-pulmonary arterial coupling in COPD? How does the severity of restriction influence $V^{\prime}{ }_{E} / V^{\prime} \mathrm{CO}_{2}$ in CPFE?

Why does a high $V^{\prime}{ }_{E} / V^{\prime} \mathrm{CO}_{2}$ predict poor peri-operative outcome in lung resection surgery?

What is the best $V^{\prime}{ }_{E} / V^{\prime} \mathrm{CO}_{2}$ parameter to predict poor surgical outcome across the spectrum of disease severity?

Does $V^{\prime}{ }_{E} / V^{\prime} \mathrm{CO}_{2}$ independently predict poor outcome in severe to very severe patients? How to best associate $V^{\prime}{ }_{E} / V^{\prime}{ }_{\mathrm{CO}_{2}}$ with clinical data to determine prognosis?

Does the longitudinal assessment of $V^{\prime}{ }_{\mathrm{E}} / V^{\prime} \mathrm{CO}_{2}$ improve prognosis estimation? What is the most sensitive parameter to detect improvement in $V^{\prime}{ }_{E} / V^{\prime} \mathrm{CO}_{2}$ ? Can exercise training and/or inspiratory muscle training improve $V^{\prime}{ }_{E} / V^{\prime} \mathrm{CO}_{2}$ in selected patients?

interventions

Do interventions aimed to improve pulmonary vascular function impact on $V^{\prime}{ }_{\mathrm{E}} / V^{\prime} \mathrm{CO}_{2}$ ?

Is there any beneficial effect of specific pharmacological interventions on $V^{\prime}{ }_{E} / V^{\prime} \mathrm{CO}_{2}$ in COPD-HF and disproportionate pulmonary hypertension?

Can long-term bronchodilation improve $V^{\prime}{ }_{\mathrm{E}} / \mathrm{V}^{\prime} \mathrm{CO}_{2}$ in selected patients?

$V_{\mathrm{D}} / V_{\mathrm{Tphys}}$ : physiological dead space; HF: heart failure; CPFE: combined pulmonary fibrosis and emphysema.

controls [18, 20, 35, 37-39, 117, 118]. Interestingly, $V_{\mathrm{E}}^{\prime} / V^{\prime} \mathrm{CO}_{2}$ nadir was increased in dyspnoeic [30], but not in asymptomatic [41], smokers. These findings are consistent with the notion that a high $V^{\prime}{ }_{E} / V^{\prime} \mathrm{CO}_{2}$ is linked to exertional dyspnoea since the early stages of the disease [117].

There is sound evidence that $V_{\mathrm{D}} / V_{\text {Tphys }}$ worsens as heart failure [119-121] and COPD (as reviewed by O'Donnell et al. [118]) progress. However, it is interesting to note that while the $V^{\prime}{ }_{\mathrm{E}}-V^{\prime} \mathrm{CO}_{2}$ slope is higher (and the $V_{E}^{\prime}$ intercept is lower) in patients with more severe heart failure [11-14, 122], the former decreases (and the latter increases) in severe to very severe COPD. Consequently, the $V^{\prime}{ }_{\mathrm{E}} / V^{\prime} \mathrm{CO}_{2}$, nadir may remain stable (albeit higher compared to a healthy subject) if the effects of a low $V^{\prime}{ }_{\mathrm{E}}-V^{\prime} \mathrm{CO}_{2}$ slope is cancelled out by a high $V_{E}^{\prime}$ intercept in severe to very severe COPD (figure 1) [39, 123]. In a large cross-sectional study, worsening dynamic hyperinflation, greater exertional dyspnoea and poorer exercise tolerance were associated with lower $V_{\mathrm{E}}^{\prime}-V_{\mathrm{CO}_{2}}^{\prime}$ slope and higher $V_{\mathrm{E}}^{\prime}$ intercept [39]. Thus, a lower $V_{\mathrm{E}}^{\prime}-V_{\mathrm{CO}_{2}}^{\prime}$ slope in advanced COPD is largely explained by worsening mechanical constraints $[45,118]$ and, in end-stage disease, by a high $P_{\mathrm{aCO}}[15,114]$. Of note, obesity in COPD also decreased $V_{\mathrm{E}}^{\prime} / V^{\prime} \mathrm{CO}_{2}$ nadir, probably due to greater ventilatory constraints [31] and, conceivably, a higher $P_{\mathrm{aCO}}$ set-point in severely obese patients. Teasing out the relative contribution of severe mechanical constraints versus a blunted $\mathrm{CO}_{2}$ chemosensitivity to decrease the $V_{\mathrm{E}}^{\prime}-V_{\mathrm{CO}_{2}}^{\prime}$ slope constitutes a formidable challenge, since these abnormalities are intrinsically linked as COPD evolves [118].

Impact of COPD comorbidities on $V^{\prime}{ }_{\mathrm{E}} / V^{\prime} \mathrm{CO}_{2}$ Pulmonary arterial hypertension (PAH) [124, 125], systolic heart failure [11-14, 122] and, to a lesser extent, coronary artery disease [126] are well known causes of a high $V_{\mathrm{E}}^{\prime} / V^{\prime} \mathrm{CO}_{2}$. The underlying mechanisms are multiple, probably involving heightened ventilatory drive from chemo-, baro- and ergoreceptors and a high $V_{\mathrm{D}} / V_{\text {Tphys }}$ [127]. Accordingly, patients with COPD and comorbid PAH do present with a high $V^{\prime}{ }_{E} / V^{\prime} \mathrm{CO}_{2}[47,48]$ with the steepest $V^{\prime}{ }^{\prime}-V_{\mathrm{CO}_{2}}^{\prime}$ slope found in severe, out-of-proportion 

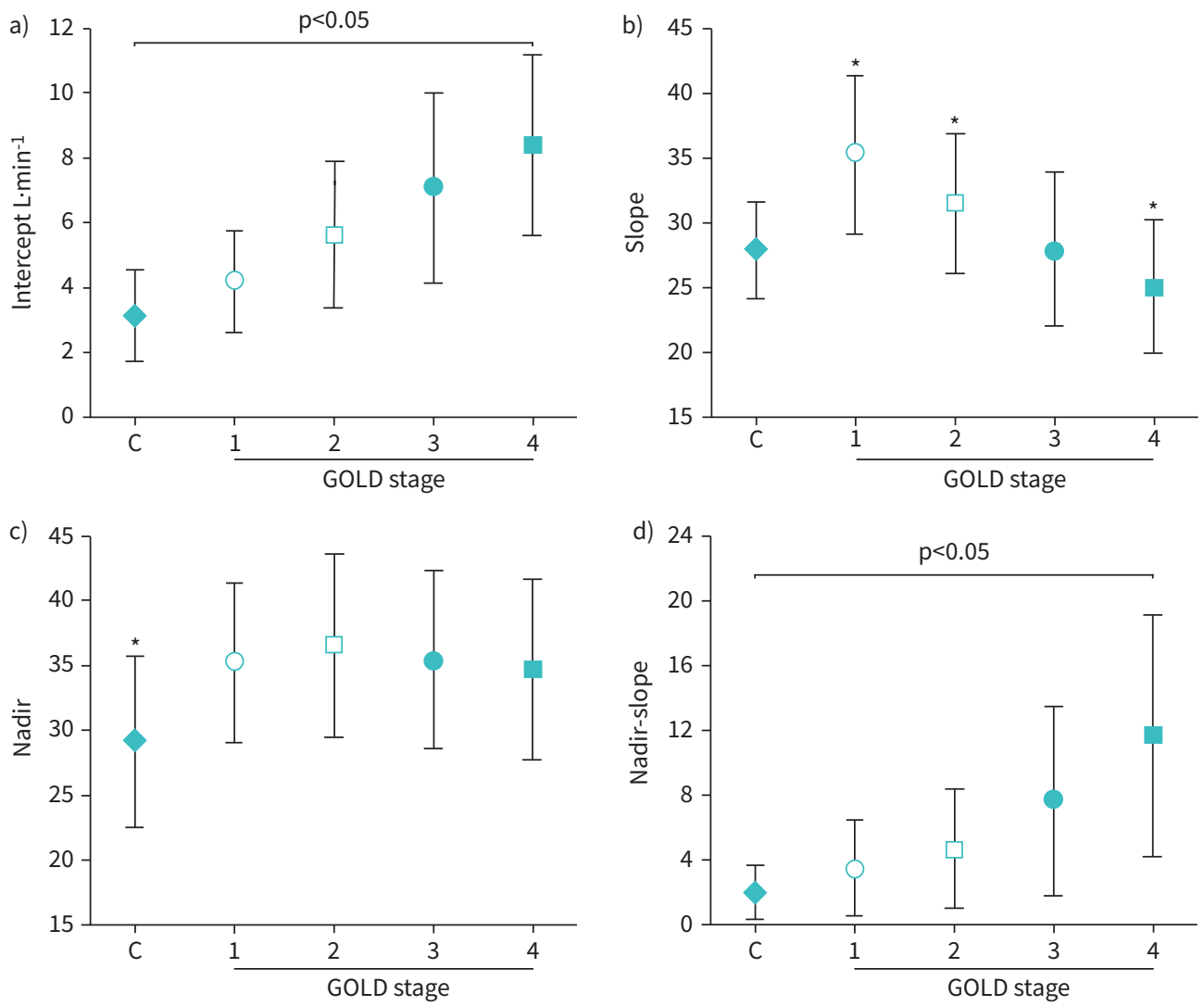

FIGURE 1 Effects of COPD severity on different parameters of the minute ventilation $\left(V_{E}^{\prime}\right) /$ carbon dioxide output $\left(V_{\mathrm{CO}_{2}}^{\prime}\right)$ relationship. a) $V_{E}^{\prime} / V^{\prime} \mathrm{CO}_{2}$ intercept increased and b) $V^{\prime} / V^{\prime} \mathrm{CO}_{2}$ slope diminished as the disease progressed from Global Lung Initiative for Chronic Obstructive Lung Disease (GOLD) spirometric stages 1 to 4 . c) As the $V^{\prime} / V^{\prime} \mathrm{CO}_{2}$ nadir depends on both slope and intercept, it remained elevated (compared to controls (C)) across disease stages. d) Increasing nadir-slope differences from GOLD stages 1 to 4 reflects the impact of a progressively higher intercept. Data are presented as mean \pm sD. ${ }^{*}: p<0.05$ different from controls. Reproduced with permission [39].

pulmonary hypertension [49]. In keeping with the concept that the mechanical constraints typical of advanced COPD may blunt the ventilatory response to exertion, the $V_{\mathrm{E}}^{\prime}-V_{\mathrm{CO}_{2}}^{\prime}$ slope did not differ in patients with severe versus very severe COPD who presented with coexistent PAH [51].

There is mounting evidence that patients with comorbid COPD-heart failure with reduced left ventricular ejection fraction present with higher $V^{\prime}{ }_{\mathrm{E}}-V^{\prime} \mathrm{CO}_{2}$ slope but lower $V_{\mathrm{E}}^{\prime}$ intercept than patients with COPD in isolation $[52,54,55,60]$. However, if the former patients are compared with those with heart failure alone, they show higher $V_{E}^{\prime}$ intercept [54, 60]. In other words, patients with COPD-heart failure typically show intermediate $V_{\mathrm{E}}^{\prime}-V^{\prime} \mathrm{CO}_{2}$ slope and $V_{\mathrm{E}}^{\prime}$ intercept compared to those with each disease alone. These findings are likely explained by the increased ventilatory stimuli brought by heart failure being partially counterbalanced by the mechanical constraints (and increased $P_{\mathrm{aCO}}$ in more advanced disease) induced by COPD [128, 129]. Of note, ARBEx et al. [55] found that exertional dyspnoea and exercise intolerance were significantly related to the overall ventilatory response to exertion in COPD-heart failure. The study by Rocha et al. [57] highlighted the importance of alveolar hyperventilation to increase $V^{\prime}{ }_{\mathrm{E}} / V^{\prime} \mathrm{CO}_{2}$ and dyspnoea at a given $V_{\mathrm{D}} / V_{\text {Tphys }}$ in COPD-heart failure (supplementary figure S4). In another investigation, these authors found that COPD-heart failure patients showing impaired aerobic function (as indicated by a blunted increase in oxygen uptake $\left(V_{\mathrm{O}_{2}}^{\prime}\right)$ as a function of work rate, suggesting impaired oxygen delivery) had a higher $V_{\mathrm{E}}^{\prime} / V^{\prime} \mathrm{CO}_{2}$ than their counterparts with more preserved aerobic metabolism [130]. These findings provide indirect support for a link between increased ergoreceptor activation and a high $V_{\mathrm{E}}^{\prime} / V^{\prime} \mathrm{CO}_{2}$ [83] caused (or worsened) by a cardiovascular comorbidity [115]. Periodic breathing, specifically ventilatory oscillations, induced by heart failure, a phenomenon associated with increased $V_{\mathrm{D}} / V_{\text {Tphys }}$ and $V^{\prime}{ }_{E} / V^{\prime} \mathrm{CO}_{2}$ [127], is associated with increased dyspnoea and reduced exercise tolerance in the presence of 

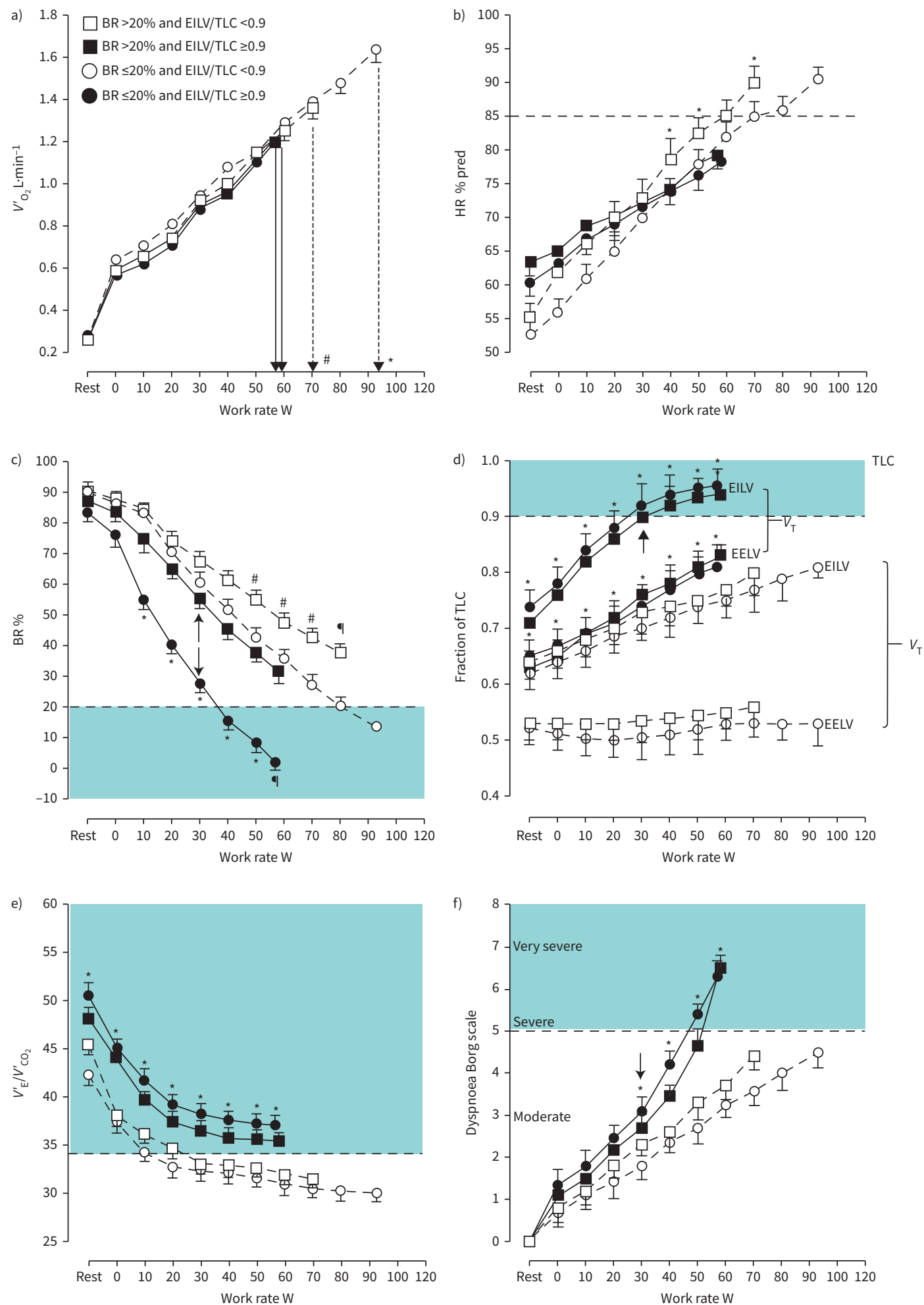

FIGURE 2 a) Metabolic, b) cardiovascular, c-e) ventilatory and f) sensory responses to symptom-limited incremental cardiopulmonary exercise testing in COPD patients presenting or not with a low breathing reserve ((BR) $\leqslant 20 \%$ or $>20 \%$, respectively) and/or high inspiratory constraints (end-inspiratory lung volume (EILV)/total lung capacity (TLC) $\geqslant 0.9$ or $<0.9$, respectively). Commonly used ranges for severe physiological and sensory impairment are highlighted (shaded areas in panels c-f). The arrows in panels c), d) and f) emphasise the exercise intensity associated with a disproportionate increase in dyspnoea relative to metabolic and ventilatory demand. Note that patients who were particularly limited due to f) exertional dyspnoea (closed symbols) 
presented with d) high inspiratory constraints and e) high ventilation $\left(V_{E}^{\prime}\right) /$ carbon dioxide output $\left(V^{\prime} \mathrm{CO}_{2}\right)$ ratio, regardless of $c$ ) the breathing reserve. ${ }^{*}: p<0.05$ versus the other groups; ${ }^{\#}: p<0.05$ versus the remaining groups; ": $p<0.05$ versus $B R \leqslant 20 \%$ or EILV/TLC $<0.9$ and BR $>20 \%$ or EILV/TLC $\geqslant 0.9$. Data are presented as mean \pm SEM. $V^{\prime} \mathrm{O}_{2}$ : oxygen uptake; HR: heart rate; EELV: end-expiratory lung volume; $V_{\mathrm{T}}$ : tidal volume. Reproduced from [44] with permission.

underlying COPD [56]. Interestingly, the oscillatory breathing ceased at high operating lung volumes when critically high inspiratory constraints prevented further increases in $V_{\mathrm{T}}$. As expected, this subgroup of patients with COPD-heart failure was particularly dyspnoeic, since the heightened ventilatory drive compounded the mechanical abnormalities [56].

Little is currently known on the potential modulating effects of emphysema extent, heart failure aetiology and heart failure with preserved ejection fraction $[131,60]$ on the $V^{\prime}{ }_{E} / V^{\prime} \mathrm{CO}_{2}$ in individual COPD-heart failure patients [128]. More subtle abnormalities in left ventricular function may increase $V_{\mathrm{E}}^{\prime} / V^{\prime} \mathrm{CO}_{2}$ in susceptible patients with COPD; in fact, coronary artery disease, even without overt heart failure, increased $V^{\prime}{ }_{E} / V^{\prime} \mathrm{CO}_{2}$ in these patients [53]. Owing to the fact that only a minority of hypoxaemic patients with COPD-heart failure have been assessed in previous studies [52, 54, 55, 60], it remains possible that a heightened hypoxic drive further increases $V^{\prime}{ }_{E} / V^{\prime} \mathrm{CO}_{2}$ in some patients. Selected interventions aimed at decreasing the ventilatory drive (such as $\beta$-blockers) have not decreased $V_{\mathrm{E}}^{\prime} / V^{\prime} \mathrm{CO}_{2}$ in patients with $\mathrm{COPD}$ [50], but this approach has not yet been tested in COPD-heart failure. There is conflicting evidence concerning a putative relationship between diastolic dysfunction and $V^{\prime}{ }_{\mathrm{E}} / V^{\prime} \mathrm{CO}_{2}[58,59]$, an issue that requires further investigation (table 2) [49].

The relevance of considering the additive effects of a high $V_{\mathrm{D}} / V_{\mathrm{Tphys}}$ and a low $P_{\mathrm{aCO}}$ to increase $V_{\mathrm{E}}^{\prime} / V^{\prime} \mathrm{CO}_{2}$ and exertional dyspnoea has been shown by CosTA et al. [62] in combined pulmonary fibrosis and emphysema (supplementary figure S5). Interestingly, $V_{\mathrm{D}} / V_{\text {Tphys }}$ was associated with the burden of emphysema (including admixed emphysema in areas of pulmonary fibrosis) and traction bronchiectasis, another potential source of wasted ventilation. In addition, it is conceivable that heightened peripheral chemostimulation [111] potentiated ventilatory stimulation in hypoxaemic patients, leading to a particularly deleterious combination of enlarged wasted ventilation, hypoxic stimulation and alveolar hyperventilation (supplementary figure S5).

$V^{\prime}{ }_{\mathrm{E}} / V^{\prime}{ }_{\mathrm{CO}_{2}}$ for risk assessment and prognosis in COPD

Resting lung function parameters (particularly $\mathrm{FEV}_{1}$ and $T_{\mathrm{LCO}}$ ) have long been used to estimate the risk of peri-operative complications in patients submitted to lung resection surgery due to lung cancer [132]. Among the exercise-based measurements, more experience has been accumulated with $V_{\mathrm{O}_{2}}^{\prime}$ peak [133]. More recently, some groups reported that a high $V_{\mathrm{E}}^{\prime}-V_{\mathrm{CO}_{2}}^{\prime}$ slope may also predict a negative outcome [64-66]. For instance, Torchio et al. [69] reported that a high $V^{\prime}{ }^{\prime}-V^{\prime} \mathrm{CO}_{2}$ slope was the strongest predictor of mortality after pneumonectomies, a finding extended by MiYAzAKı et al. [70] to less extensive anatomical lung resections. EllenBerger et al. [71] found that a particularly high $V_{E}^{\prime} / V_{\mathrm{CO}_{2}}^{\prime}(>40)$ predicted poor survival after radical surgery for lung cancer. It remains unclear why a high $V^{\prime}{ }_{\mathrm{E}} / V^{\prime} \mathrm{CO}_{2}$ predicts a negative surgical outcome in this context, but the reasons are probably multiple, including more severe emphysema, higher pulmonary vascular pressures, poorer cardiac performance, heightened sympathetic drive, exertional hypoxaemia and increased ergoreceptor stimulation due to severe deconditioning [134]. However, it should be recognised that the reduction in $V_{E}^{\prime} / V^{\prime} \mathrm{CO}_{2}$ in severe to very severe COPD (figure 1) may decrease its predictive power in these patients, an issue that needs further investigation (table 2).

Similar to heart failure [11-14, 122], a high $V^{\prime}{ }_{E} / V^{\prime} \mathrm{CO}_{2}\left(V^{\prime}{ }_{\mathrm{E}} / V^{\prime} \mathrm{CO}_{2}\right.$ nadir $\left.\geqslant 34\right)$ predicts poor survival in patients with COPD. Of note, lung hyperinflation added to $V^{\prime}{ }_{\mathrm{E}} / V^{\prime} \mathrm{CO}_{2}$ to predict mortality due to respiratory and nonrespiratory causes (figure 3) [67]. Increased sympathetic stimulation, as inferred by a slow decrease in post-exercise heart rate, was observed in COPD patients with higher and worsening mechanical constraints [42], providing a potential clue for the mechanisms underlying the association between these variables and the risk of a future negative event. Furthermore, a high $V^{\prime}{ }_{\mathrm{E}} / V^{\prime} \mathrm{CO}_{2}$ nadir compound impaired right ventricular systolic function to predict poor outcome in COPD-heart failure [68]. A high $V^{\prime}{ }_{\mathrm{E}}-V^{\prime} \mathrm{CO}_{2}$ slope has been associated with increasing risk of hospitalisation in this specific subpopulation [61]. Pending experimental confirmation in larger studies, $V^{\prime}{ }_{E} / V^{\prime} \mathrm{CO}_{2}$ might become a relevant effort-independent prognostic parameter in patients with COPD (table 2). 

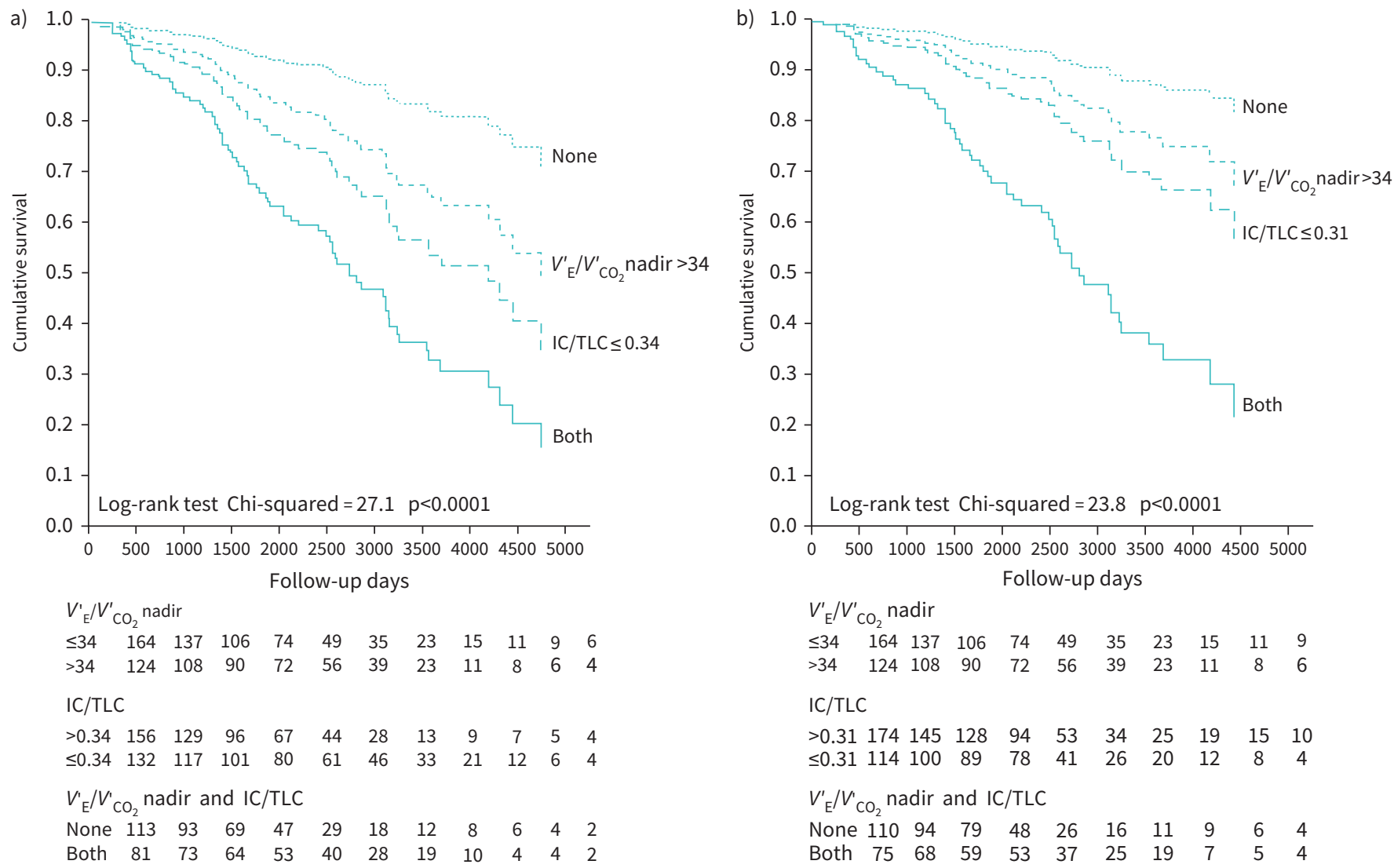

FIGURE 3 Value of high ventilation $\left(V_{E}^{\prime}\right) /$ carbon dioxide output $\left(V^{\prime} \mathrm{CO}_{2}\right)$ nadir in isolation and associated with resting lung hyperinflation (low inspiratory capacity (IC)/total lung capacity (TLC) ratio) to predict a) all-cause and b) respiratory mortality in patients with mild to severe COPD. Reproduced from [67] with permission.

Effects of interventions on $V^{\prime}{ }_{\mathrm{E}} / V^{\prime} \mathrm{CO}_{2}$ in COPD

The effects of interventions on $V^{\prime}{ }_{E} / V^{\prime} \mathrm{CO}_{2}$ are highly variable, depending on the main mechanism of action. Thus, interventions which may lessen the mechanical constraints (heliox [76, 80, 81, 86], lobectomy [79] and bronchodilators $[75,77,85])$ typically increased $V_{\mathrm{E}}^{\prime}$ at a given $V_{\mathrm{CO}_{2}}^{\prime}$. In other circumstances where the main mechanism of action was probably related to a lower $V_{\mathrm{D}}$ and/or a higher $V_{\mathrm{T}}$ (single [72] and double lung [82] transplantation and lung volume reduction surgery [84, 87]), $V_{\mathrm{E}}^{\prime}$ decreased at a given $V^{\prime} \mathrm{CO}_{2}$. Similarly, interventions aimed at lowering the respiratory neural drive (supplemental oxygen [82, 95], spinal anaesthesia [83]) also decreased $V_{\mathrm{E}}^{\prime} / V^{\prime} \mathrm{CO}_{2}$. At least theoretically, exercise training may lessen $V_{\mathrm{E}}^{\prime} / V^{\prime} \mathrm{CO}_{2}$ in some patients due to high $V_{\mathrm{T}}$ leading to a low $V_{\mathrm{D}} / V_{\text {Tphys }}$ as well as delaying metabolic acidosis, thereby reducing afferent stimuli from the active peripheral muscles [135]. These mechanistic considerations raise the question of why inhaled bronchodilators have not been reported to change the $V_{\mathrm{E}}^{\prime} / V^{\prime} \mathrm{CO}_{2}$ in $\mathrm{COPD}$ [136]. In fact, Elbehairy et al. [92] found that despite appreciable lung deflation after acute bronchodilation, $V_{\mathrm{D}} / V_{\mathrm{Tphys}}$ and $V_{\mathrm{E}}^{\prime} / V^{\prime} \mathrm{CO}_{2}$ both remained unaltered. These findings highlight the importance of wasted ventilation in regulating $V_{\mathrm{E}}^{\prime} / V^{\prime} \mathrm{CO}_{2}$ in COPD while suggesting that the higher $V_{\mathrm{T}}$ and regional alveolar ventilation after bronchodilation occurs preferentially directed in areas which were already better ventilated. Nevertheless, this topic merits more detailed analysis in longer trials (table 2).

\section{Applying $V^{\prime}{ }_{E} / V^{\prime}{ }_{\mathrm{CO}_{2}}$ to clinical management of COPD}

The data summarised in table 1 provide some clues on the specific scenarios in which measuring $V_{\mathrm{E}}^{\prime} / V^{\prime} \mathrm{CO}_{2}$ may have practical implications for the management of patients with COPD. Exertional dyspnoea is a ubiquitous symptom across the range of COPD severity. However, in some circumstances, it is chiefly related to unfitness, obesity, hyperventilation or comorbidities. Establishing a link between a high $V_{\mathrm{E}}^{\prime} / V^{\prime} \mathrm{CO}_{2}$ and dyspnoea in patients with only mildly to moderately reduced $\mathrm{FEV}_{1}$ might prompt a more proactive approach to bronchodilator treatment. A similar line of reasoning applies to patients with disproportionate 
dyspnoea relative to resting lung function impairment. In both circumstances, it is important to jointly analyse $V_{\mathrm{E}}^{\prime} / V^{\prime} \mathrm{CO}_{2}$ and noninvasive measurements of lung mechanics as they provide complementary information (figure 2). A high $V^{\prime}{ }_{\mathrm{E}} / V^{\prime} \mathrm{CO}_{2}$ coupled with severely increased operating lung volumes might also suggest that the patient is poorly prepared to face the challenges brought by an acute exacerbation; thus, regardless of $\mathrm{FEV}_{1}$, the patient might benefit from closer follow-up and optimisation of anti-exacerbation measures. Marked increases in $V_{E}^{\prime} / V^{\prime} \mathrm{CO}_{2}$ might raise concerns regarding associated pulmonary vascular disease or, if appropriate, heart failure. This is particularly true when there is only a trivial burden of emphysema on high-resolution computed tomography to otherwise explain a high $V_{\mathrm{E}}^{\prime} / V^{\prime} \mathrm{CO}_{2}$. Conversely, a lower-than-expected $V_{E}^{\prime} / V^{\prime} \mathrm{CO}_{2}$ might be related to morbid obesity or another potential cause of blunted ventilatory response, including severe sleep disordered breathing, neuromuscular disease and hypercapnic respiratory failure of other aetiology. In fact, PAOLETTi et al. [17] showed that $V^{\prime}{ }_{\mathrm{E}} / V^{\prime} \mathrm{CO}_{2}$ may decrease in more advanced emphysema as the severe mechanical constraints preclude appropriate ventilatory response to metabolic demand, despite an enlarged dead space. It follows that a low $V_{\mathrm{E}}^{\prime} / V^{\prime} \mathrm{CO}_{2}$ in patients with substantial emphysema signals for the dominance of mechanical abnormalities over the gas exchange disturbances. Therefore, in the right clinical context, this piece of information might be useful to select patients more likely to derive benefit from interventions aimed to release the mechanical constraints, e.g. volume reduction surgery. A high $V^{\prime}{ }_{E} / V^{\prime} \mathrm{CO}_{2}$ in COPD patients referred for resection surgery due to lung cancer should raise concerns about the increased risk of peri-operative complications. If feasible, a more limited resection might be advisable in these patients. Finally, documenting a lower $V_{E}^{\prime} / V^{\prime} \mathrm{CO}_{2}$ after lung transplantation or lung volume reduction surgery might provide objective evidence attesting the efficacy of these expensive treatment approaches.

\section{Conclusions}

The relevance of abnormalities in $V_{\mathrm{E}}^{\prime} / V^{\prime} \mathrm{CO}_{2}$ during exercise has only recently become a target for systematic assessment in COPD (table 1). Whereas the $V^{\prime}{ }^{\prime}-V_{\mathrm{CO}_{2}}^{\prime}$ slope and the $V_{\mathrm{E}}^{\prime} / V^{\prime} \mathrm{CO}_{2}$ nadir are frequently increased in mild to moderate COPD, increasing ventilatory constraints may lead to a "preserved" $V_{\mathrm{E}}^{\prime}-V_{\mathrm{CO}_{2}}^{\prime}$ slope in more advanced COPD. A higher $V_{\mathrm{E}}^{\prime}$ intercept may partially counterbalance the latter effect; thus, the $V_{\mathrm{E}}^{\prime} / V^{\prime} \mathrm{CO}_{2}$ nadir may still be elevated in these patients. However, in end-stage COPD, the mechanical constraints (and the associated hypercapnia) may eventually prevail, leading to a “normal” or low $V_{E}^{\prime} / V^{\prime} \mathrm{CO}_{2}$ nadir. Overall, a high $V_{\mathrm{E}}^{\prime} / V^{\prime} \mathrm{CO}_{2}$ frequently exposes clinically significant $V^{\prime} / Q^{\prime}$ distribution though alveolar hyperventilation may also contribute, particularly in the presence of cardiovascular comorbidities or lung fibrosis. Published evidence (table 1) indicates that the $V_{\mathrm{E}}^{\prime} / V^{\prime} \mathrm{CO}_{2}$ nadir is a particularly useful index of abnormal uncoupling between ventilation and metabolic demand in COPD, being linked to important clinical outcomes such as dyspnoea, reduced exercise capacity and even mortality. In daily practice, $V_{E}^{\prime} / V^{\prime} \mathrm{CO}_{2}$ measurements are particularly useful in the individualised assessment of exercise intolerance in mild to moderate COPD, notably in individuals with disproportionate exertional dyspnoea. Providing evidence-based answers to the questions posed in table 2 may prove valuable to extend the clinical applications of $V^{\prime}{ }_{\mathrm{E}} / V^{\prime} \mathrm{CO}_{2}$ in this patient population.

Provenance: Commissioned article, peer reviewed.

Previous articles in this series: No. 1: Laveneziana P, Di Paolo M, Palange P. The clinical value of cardiopulmonary exercise testing in the modern era. Eur Respir Rev 2021; 30: 200187. No. 2: Agnostoni P, Sciomer S, Palermo P, et al. Minute ventilation/carbon dioxide production in chronic heart failure. Eur Respir Rev 2021; 30: 200141. No. 3: Watson M, Ionescu MF, Sylvester K, et al. Minute ventilation/carbon dioxide production in patients with dysfunctional breathing. Eur Respir Rev 2021; 30: 200182. No. 4: Ward SA. Ventilation/carbon dioxide output relationships during exercise in health. Eur Respir Rev 2021; 30: 200160. No. 5: Collins SÉ, Phillips DB, Brotto AR, et al. Ventilatory efficiency in athletes, asthma and obesity. Eur Respir Rev 2021; 30: 200206. No. 6: Schaegger MR, Guenette JA, Jensen D. Impact of ageing and pregnancy on the minute ventilation/carbon dioxide production response to exercise. Eur Respir Rev 2021; 30: 200225. No. 7: Weatherald J, Philipenko B, Montani D, et al., Ventilatory efficiency in pulmonary vascular diseases. Eur Respir Rev 2021; 30: 200214.

Conflict of interest: None declared.

Support statement: J. Alberto Neder has been funded by a New Clinician Scientist Program from the Southeastern Ontario Academic Medical Association (SEAMO), Canada. The funder had no role in the study design, data collection and analysis, or preparation of the manuscript. 
References

1 Whipp BJ, Ward SA, Wasserman K. Ventilatory responses to exercise and their control in man. Am Rev Respir Dis 1984; 129: S17-S20.

2 Whipp BJ, Ward SA. Determinants and control of breathing during muscular exercise. Br J Sports Med 1998; 32: 199-211.

3 Neder JA, Jones PW, Nery LE, et al. Determinants of the exercise endurance capacity in patients with chronic obstructive pulmonary disease. The power-duration relationship. Am J Respir Crit Care Med 2000; 162: 497-504.

4 O'Donnell DE, Elbehairy AF, Faisal A, et al. Exertional dyspnoea in COPD: the clinical utility of cardiopulmonary exercise testing. Eur Respir Rev 2016; 25: 333-347.

5 Neder JA. Ventilatory demand-capacity imbalance during incremental exercise in COPD: an in silico perspective. Eur Respir J 2020; 56: 2000495.

$6 \quad$ Whipp BJ. The hyperpnea of dynamic muscular exercise. Exerc Sport Sci Rev 1977; 5: 295-311.

7 Whipp BJ. Control of the exercise hyperpnea: the unanswered question. Adv Exp Med Biol 2008; 605: 16-21.

8 Sun X-G, Hansen JE, Garatachea N, et al. Ventilatory efficiency during exercise in healthy subjects. Am J Respir Crit Care Med 2002; 166: 1443-1448.

9 Barron A, Dhutia N, Mayet J, et al. Test-retest repeatability of cardiopulmonary exercise test variables in patients with cardiac or respiratory disease. Eur J Prev Cardiol 2014; 21: 445-453.

10 Neder JA, Berton DC, Arbex FF, et al. Physiological and clinical relevance of exercise ventilatory efficiency in COPD. Eur Respir J 2017; 49: 1602036.

11 ERS Task Force, Palange P, Ward SA, et al. Recommendations on the use of exercise testing in clinical practice. Eur Respir J 2007; 29: 185-209.

12 Cahalin LP, Chase P, Arena R, et al. A meta-analysis of the prognostic significance of cardiopulmonary exercise testing in patients with heart failure. Heart Fail Rev 2013; 18: 79-94.

13 Corrà U, Piepoli MF, Adamopoulos S, et al. Cardiopulmonary exercise testing in systolic heart failure in 2014: the evolving prognostic role: a position paper from the committee on exercise physiology and training of the heart failure association of the ESC. Eur J Heart Fail 2014; 16: 929-941.

14 Malhotra R, Bakken K, D’Elia E, et al. Cardiopulmonary exercise testing in heart failure. JACC Heart Fail 2016; 4: 607-616.

15 O'Donnell DE, D'Arsigny C, Fitzpatrick M, et al. Exercise hypercapnia in advanced chronic obstructive pulmonary disease: the role of lung hyperinflation. Am J Respir Crit Care Med 2002; 166: 663-668.

16 Nakamoto FP, Neder JA, Maia J, et al. Skeletal muscle ergoreflex overactivity is not related to exercise ventilatory inefficiency in non-hypoxaemic patients with COPD. Eur J Appl Physiol 2007; 101: 705-712.

17 Paoletti P, De Filippis F, Fraioli F, et al. Cardiopulmonary exercise testing (CPET) in pulmonary emphysema. Respir Physiol Neurobiol 2011; 179: 167-173.

18 Chin RC, Guenette JA, Cheng S, et al. Does the respiratory system limit exercise in mild chronic obstructive pulmonary disease? Am J Respir Crit Care Med 2013; 187: 1315-1323.

19 Neder JA, O'Donnell CDJ, Cory J, et al. Ventilation distribution heterogeneity at rest as a marker of exercise impairment in mild-to-advanced COPD. COPD 2015; 12: 249-256.

20 Elbehairy AF, Ciavaglia CE, Webb KA, et al. Pulmonary gas exchange abnormalities in mild chronic obstructive pulmonary disease. Implications for dyspnea and exercise intolerance. Am J Respir Crit Care Med 2015; 191: 1384-1394.

21 Crisafulli E, Alfieri V, Silva $\mathrm{M}$, et al. Relationships between emphysema and airways metrics at high-resolution computed tomography (HRCT) and ventilatory response to exercise in mild to moderate COPD patients. Respir Med 2016; 117: 207-214.

22 Elbehairy AF, Faisal A, Guenette JA, et al. Resting physiological correlates of reduced exercise capacity in smokers with mild airway obstruction. COPD 2017; 14: 267-275.

23 Jones JH, Zelt JT, Hirai DM, et al. Emphysema on thoracic CT and exercise ventilatory inefficiency in mild-to-moderate COPD. COPD 2017; 14: 210-218.

24 Behnia M, Wheatley CM, Avolio A, et al. Alveolar-capillary reserve during exercise in patients with chronic obstructive pulmonary disease. Int J Chron Obstruct Pulmon Dis 2017; 12: 3115-3122.

25 Smith BM, Jensen D, Brosseau M, et al. Impact of pulmonary emphysema on exercise capacity and its physiological determinants in chronic obstructive pulmonary disease. Sci Rep 2018; 8: 15745.

26 Tedjasaputra V, van Diepen S, Phillips DB, et al. Pulmonary capillary blood volume response to exercise is diminished in mild chronic obstructive pulmonary disease. Respir Med 2018; 145: 57-65.

27 Elbehairy AF, O'Donnell CD, Abd Elhameed A, et al. Low resting diffusion capacity, dyspnea, and exercise intolerance in chronic obstructive pulmonary disease. J Appl Physiol 2019; 127: 1107-1116.

28 Rinaldo RF, Mondoni M, Comandini S, et al. The role of phenotype on ventilation and exercise capacity in patients affected by COPD: a retrospective study. Multidiscip Respir Med 2020; 15: 476.

29 Palange $\mathrm{P}$, Forte $\mathrm{S}$, Onorati $\mathrm{P}$, et al. Ventilatory and metabolic adaptations to walking and cycling in patients with COPD. J Appl Physiol 2000; 88: 1715-1720. 
Ofir D, Laveneziana P, Webb KA, et al. Mechanisms of dyspnea during cycle exercise in symptomatic patients with GOLD stage I chronic obstructive pulmonary disease. Am J Respir Crit Care Med 2008; 177: 622-629.

Ora J, Laveneziana P, Ofir D, et al. Combined effects of obesity and chronic obstructive pulmonary disease on dyspnea and exercise tolerance. Am J Respir Crit Care Med 2009; 180: 964-971.

Guenette JA, Jensen D, Webb KA, et al. Sex differences in exertional dyspnea in patients with mild COPD: physiological mechanisms. Respir Physiol Neurobiol 2011; 177: 218-227.

Caviedes IR, Delgado I, Soto R. Ventilatory inefficiency as a limiting factor for exercise in patients with COPD. Respir Care 2012; 57: 583-589.

Teopompi E, Tzani $\mathrm{P}$, Aiello $\mathrm{M}$, et al. Excess ventilation and ventilatory constraints during exercise in patients with chronic obstructive pulmonary disease. Respir Physiol Neurobiol 2014; 197: 9-14.

Guenette JA, Chin RC, Cheng S, et al. Mechanisms of exercise intolerance in global initiative for chronic obstructive lung disease grade 1 COPD. Eur Respir J 2014; 44: 1177-1187.

Ciavaglia CE, Guenette JA, Ora J, et al. Does exercise test modality influence dyspnoea perception in obese patients with COPD? Eur Respir J 2014; 43: 1621-1630.

O'Donnell DE, Maltais F, Porszasz J, et al. The continuum of physiological impairment during treadmill walking in patients with mild-to-moderate COPD: patient characterization phase of a randomized clinical trial. PLoS One 2014; 9: e96574.

Elbehairy AF, Raghavan N, Cheng S, et al. Physiologic characterization of the chronic bronchitis phenotype in GOLD grade IB COPD. Chest 2015; 147: 1235-1245.

Neder JA, Arbex FF, Alencar MCN, et al. Exercise ventilatory inefficiency in mild to end-stage COPD. Eur Respir J 2015; 45: 377-387.

Faisal A, Alghamdi BJ, Ciavaglia CE, et al. Common mechanisms of dyspnea in chronic interstitial and obstructive lung disorders. Am J Respir Crit Care Med 2016; 193: 299-309.

Elbehairy AF, Guenette JA, Faisal A, et al. Mechanisms of exertional dyspnoea in symptomatic smokers without COPD. Eur Respir J 2016; 48: 694-705.

Crisafulli E, Vigna $\mathrm{M}$, lelpo $\mathrm{A}$, et al. Heart rate recovery is associated with ventilatory constraints and excess ventilation during exercise in patients with chronic obstructive pulmonary disease. Eur J Prev Cardiol 2018; 25: 1667-1674.

Bravo DM, Gimenes AC, Amorim BC, et al. Excess ventilation in COPD: implications for dyspnoea and tolerance to interval exercise. Respir Physiol Neurobiol 2018; 250: 7-13.

Neder JA, Berton DC, Marillier M, et al. Inspiratory constraints and ventilatory inefficiency are superior to breathing reserve in the assessment of exertional dyspnea in COPD. COPD 2019; 16: 174-181.

Kuint R, Berkman N, Nusair S. Ventilatory compensation during the incremental exercise test is inversely correlated with air trapping in COPD. F1000Res 2019; 8: 1661.

Neder JA, Berton DC, Marillier M, et al. Resting $V^{\prime}{ }_{\mathrm{E}} / V^{\prime} \mathrm{CO}_{2}$ adds to inspiratory capacity to predict the burden of exertional dyspnoea in COPD. Eur Respir J 2020; 56: 1902434.

Holverda S, Bogaard HJ, Groepenhoff H, et al. Cardiopulmonary exercise test characteristics in patients with chronic obstructive pulmonary disease and associated pulmonary hypertension. Respiration 2008; 76: 160-167.

Vonbank K, Funk GC, Marzluf B, et al. Abnormal pulmonary arterial pressure limits exercise capacity in patients with COPD. Wien Klin Wochenschr 2008; 120: 749-755.

Boerrigter BG, Bogaard HJ, Trip P, et al. Ventilatory and cardiocirculatory exercise profiles in COPD: the role of pulmonary hypertension. Chest 2012; 142: 1166-1174.

Thirapatarapong W, Armstrong HF, Bartels MN. Exercise capacity and ventilatory response during exercise in COPD patients with and without $\beta$ blockade. Lung 2013; 191: 531-536.

Thirapatarapong W, Armstrong HF, Bartels MN. Comparing cardiopulmonary exercise testing in severe COPD patients with and without pulmonary hypertension. Heart Lung Circ 2014; 23: 833-840.

Teopompi E, Tzani P, Aiello M, et al. Ventilatory response to carbon dioxide output in subjects with congestive heart failure and in patients with COPD with comparable exercise capacity. Respir Care 2014; 59: 1034-1041.

Thirapatarapong W, Armstrong HF, Bartels MN. Comparison of cardiopulmonary exercise testing variables in COPD patients with and without coronary artery disease. Heart Lung 2014; 43: 146-151.

Apostolo A, Laveneziana P, Palange P, et al. Impact of chronic obstructive pulmonary disease on exercise ventilatory efficiency in heart failure. Int J Cardiol 2015; 189: 134-140.

Arbex FF, Alencar MC, Souza A, et al. Exercise ventilation in COPD: influence of systolic heart failure. COPD 2016; 13: 693-699.

Rocha A, Arbex FF, Alencar MCN, et al. Physiological and sensory consequences of exercise oscillatory ventilation in heart failure-COPD. Int J Cardiol 2016; 224: 447-453.

Rocha A, Arbex FF, Sperandio PA, et al. Excess ventilation in chronic obstructive pulmonary disease-heart failure overlap. Implications for dyspnea and exercise intolerance. Am J Respir Crit Care Med 2017; 196: 1264-1274.

Muller PT, Utida KAM, Augusto TRL, et al. Left ventricular diastolic dysfunction and exertional ventilatory inefficiency in COPD. Respir Med 2018; 145: 101-109. 
Cherneva RV, Gospodinova MV, Denchev SV, et al. Stress echocardiography for left ventricular diastolic dysfunction detection in patients with non-severe chronic obstructive pulmonary disease: a cross-sectional study. Croat Med J 2019; 60: 449-457.

Smith JR, Van Iterson EH, Johnson BD, et al. Exercise ventilatory inefficiency in heart failure and chronic obstructive pulmonary disease. Int J Cardiol 2019; 274: 232-236.

Goulart CDL, Dos Santos PB, Caruso FR, et al. The value of cardiopulmonary exercise testing in determining severity in patients with both systolic heart failure and COPD. Sci Rep 2020; 10: 4309.

Costa CM, Neder JA, Verrastro CG, et al. Uncovering the mechanisms of exertional dyspnoea in combined pulmonary fibrosis and emphysema. Eur Respir J 2020; 55: 1901319.

Plachi F, Balzan FM, Fröhlich LF, et al. Exertional dyspnoea-ventilation relationship to discriminate respiratory from cardiac impairment. Eur Respir J 2020; 55: 1901518.

Torchio R, Guglielmo M, Giardino R, et al. Exercise ventilatory inefficiency and mortality in patients with chronic obstructive pulmonary disease undergoing surgery for non-small-cell lung cancer. Eur $J$ Cardiothorac Surg 2010; 38: 14-19.

Brunelli A, Belardinelli R, Pompili $C$, et al. Minute ventilation-to-carbon dioxide output $\left(V^{\prime}{ }_{E} / V^{\prime} \mathrm{CO}_{2}\right)$ slope is the strongest predictor of respiratory complications and death after pulmonary resection. Ann Thorac Surg 2012; 93: 1802-1806.

Shafiek H, Valera JL, Togores B, et al. Risk of postoperative complications in chronic obstructive lung diseases patients considered fit for lung cancer surgery: beyond oxygen consumption. Eur J Cardiothorac Surg 2016; 50: 772-779.

Neder JA, Alharbi A, Berton DC, et al. Exercise ventilatory inefficiency adds to lung function in predicting mortality in COPD. COPD 2016; 13: 416-424.

Alencar MC, Arbex F, Souza A, et al. Does exercise ventilatory inefficiency predict poor outcome in heart failure patients with COPD? J Cardiopulm Rehab Prev 2016; 36: 454-459.

Torchio R, Mazzucco A, Guglielmo M, et al. Minute ventilation to carbon dioxide output $\left(V^{\prime}{ }_{E} / V^{\prime} \mathrm{CO}_{2}\right.$ slope $)$ is the strongest death predictor before larger lung resections. Monaldi Arch Chest Dis 2017; 87: 817.

Miyazaki T, Callister MEJ, Franks $\mathrm{K}$, et al. Minute ventilation-to-carbon dioxide slope is associated with postoperative survival after anatomical lung resection. Lung Cancer 2018; 125: 218-222.

Ellenberger C, Garofano N, Reynaud T, et al. Patient and procedural features predicting early and mid-term outcome after radical surgery for non-small cell lung cancer. J Thorac Dis 2018; 10: 6020-6029.

Orens JB, Becker FS, Lynch JP, et al. Cardiopulmonary exercise testing following allogeneic lung transplantation for different underlying disease states. Chest 1995; 107: 144-149.

Somfay A, Porszasz J, Lee SM, et al. Dose-response effect of oxygen on hyperinflation and exercise endurance in nonhypoxaemic COPD patients. Eur Respir J 2001; 18: 77-84.

O'Donnell DE, D'Arsigny C, Webb KA. Effects of hyperoxia on ventilatory limitation during exercise in advanced chronic obstructive pulmonary disease. Am J Respir Crit Care Med 2001; 163: 892-898.

O'Donnell DE, Voduc N, Fitzpatrick M, et al. Effect of salmeterol on the ventilatory response to exercise in chronic obstructive pulmonary disease. Eur Respir J 2004; 24: 86-94.

Palange $\mathrm{P}$, Valli $\mathrm{G}$, Onorati $\mathrm{P}$, et al. Effect of heliox on lung dynamic hyperinflation, dyspnea, and exercise endurance capacity in COPD patients. J Appl Physiol 2004; 97: 1637-1642.

O'Donnell DE, Flüge T, Gerken F, et al. Effects of tiotropium on lung hyperinflation, dyspnoea and exercise tolerance in COPD. Eur Respir J 2004; 23: 832-840.

Porszasz J, Emtner M, Goto S, et al. Exercise training decreases ventilatory requirements and exerciseinduced hyperinflation at submaximal intensities in patients with COPD. Chest 2005; 128: 2025-2034.

Bobbio A, Chetta A, Carbognani P, et al. Changes in pulmonary function test and cardio-pulmonary exercise capacity in COPD patients after lobar pulmonary resection. Eur J Cardiothorac Surg 2005; 28: 754-758.

Eves ND, Petersen SR, Haykowsky MJ, et al. Helium-hyperoxia, exercise, and respiratory mechanics in chronic obstructive pulmonary disease. Am J Respir Crit Care Med 2006; 174: 763-771.

Chiappa GR, Queiroga F, Meda E, et al. Heliox improves oxygen delivery and utilization during dynamic exercise in patients with chronic obstructive pulmonary disease. Am J Respir Crit Care Med 2009; 179: 1004-1010.

82 Habedank D, Ewert R, Hummel M, et al. The effects of bilateral lung transplantation on ventilatory efficiency, oxygen uptake and the right heart: a two-yr follow-up. Clin Transplant 2011; 25: E38-E45.

Gagnon P, Bussières JS, Ribeiro F, et al. Influences of spinal anesthesia on exercise tolerance in patients with chronic obstructive pulmonary disease. Am J Respir Crit Care Med 2012; 186: 606-615.

Kim V, Kretschman DM, Sternberg AL, et al. Weight gain after lung reduction surgery is related to improved lung function and ventilatory efficiency. Am J Respir Crit Care Med 2012; 186: 1109-1116.

Guenette JA, Webb KA, O'Donnell DE. Effect of fluticasone/salmeterol combination on dyspnea and respiratory mechanics in mild-to-moderate COPD. Respir Med 2013; 107: 708-716.

Queiroga F, Nunes M, Meda E, et al. Exercise tolerance with helium-hyperoxia versus hyperoxia in hypoxaemic patients with COPD. Eur Respir J 2013; 42: 362-370. 
Armstrong HF, Dussault NE, Thirapatarapong W, et al. Ventilatory efficiency before and after lung volume reduction surgery. Respir Care 2015; 60: 63-71.

Gloeckl R, Richter P, Winterkamp S, et al. Cardiopulmonary response during whole-body vibration training in patients with severe COPD. ERJ Open Res 2017; 3: 00101-2016.

Langer D, Ciavaglia C, Faisal A, et al. Inspiratory muscle training reduces diaphragm activation and dyspnea during exercise in COPD. J Appl Physiol 2018; 125: 381-392.

O'Donnell DE, Elbehairy AF, Faisal A, et al. Sensory-mechanical effects of a dual bronchodilator and its anticholinergic component in COPD. Respir Physiol Neurobiol 2018; 247: 116-125.

Behnia M, Wheatley CM, Avolio A, et al. Influence of dietary nitrate supplementation on lung function and exercise gas exchange in COPD patients. Nitric Oxide 2018; 76: 53-61.

Elbehairy AF, Webb KA, Laveneziana P, et al. Acute bronchodilator therapy does not reduce wasted ventilation during exercise in COPD. Respir Physiol Neurobiol 2018; 252-253: 64-71.

Perrotta F, Cennamo A, Cerqua FS, et al. Effects of a high-intensity pulmonary rehabilitation program on the minute ventilation/carbon dioxide output slope during exercise in a cohort of patients with COPD undergoing lung resection for non-small cell lung cancer. J Bras Pneumol 2019; 45: e20180132.

Gravier F-E, Bonnevie T, Boujibar F, et al. Effect of prehabilitation on ventilatory efficiency in non-small cell lung cancer patients: a cohort study. J Thorac Cardiovasc Surg 2019; 157: 2504-2512.

Hasler ED, Saxer S, Schneider SR, et al. Effect of breathing oxygen-enriched air on exercise performance in patients with chronic obstructive pulmonary disease: randomized, placebo-controlled, cross-over trial. Respiration 2020; 99: 213-224.

Boutou AK, Nair A, Douraghi-Zadeh D, et al. A combined pulmonary function and emphysema score prognostic index for staging in chronic obstructive pulmonary disease. PLoS One 2014; 9: e111109.

Barbera JA, Roca J, Ramirez J, et al. Gas exchange during exercise in mild chronic obstructive pulmonary disease. Correlation with lung structure. Am Rev Respir Dis 1991; 144: 520-525.

Wagner PD, Dantzker DR, Dueck R, et al. Ventilation-perfusion inequality in chronic obstructive pulmonary disease. J Clin Invest 1977; 59: 203-216.

Agustí AG, Barberá JA, Roca J, et al. Hypoxic pulmonary vasoconstriction and gas exchange during exercise in chronic obstructive pulmonary disease. Chest 1990; 97: 268-275.

Robertson HT. Dead space: the physiology of wasted ventilation. Eur Respir J 2015; 45: 1704-1716.

Hueper K, Vogel-Claussen J, Parikh MA, et al. Pulmonary microvascular blood flow in mild chronic obstructive pulmonary disease and emphysema. The MESA COPD study. Am J Respir Crit Care Med 2015; 192: 570-580.

Neder JA, Berton DC, Muller PT, et al. Incorporating lung diffusing capacity for carbon monoxide in clinical decision making in chest medicine. Clin Chest Med 2019; 40: 285-305.

Auerbach O, Hammond EC, Garfinkel L, et al. Relation of smoking and age to emphysema. Whole-lung section study. N Engl J Med 1972; 286: 853-857.

Dilektasli AG, Porszasz J, Stringer WW, et al. Physiologic effects of oxygen supplementation during exercise in chronic obstructive pulmonary disease. Clin Chest Med 2019; 40: 385-395.

Johnson RL. Gas exchange efficiency in congestive heart failure. Circulation 2000; 101: 2774-2776.

Oren A, Wasserman $\mathrm{K}$, Davis JA, et al. Effect of $\mathrm{CO}_{2}$ set point on ventilatory response to exercise. $J$ App Physiol Respir Environ Exerc Physiol 1981; 51: 185-189.

Naeije R, Faoro V. The great breathlessness of cardiopulmonary diseases. Eur Respir J 2018; 51: 1702517.

Jones NL, McHardy GJ, Naimark A, et al. Physiological dead space and alveolar-arterial gas pressure differences during exercise. Clin Sci 1966; 31: 19-29.

West JB. Causes of carbon dioxide retention in lung disease. N Engl J Med 1971; 284: 1232-1236.

Robertson HT. Dead space: the physiology of wasted ventilation. Eur Respir J 2015; 45: 1704-1716.

Dempsey JA, Smith CA. Pathophysiology of human ventilatory control. Eur Respir J 2014; 44: 495-512.

Ward SA, Whipp BJ. Ventilatory control during exercise with increased external dead space. J Appl Physiol Respir Environ Exerc Physiol 1980; 48: 225-231.

3 Gargiulo P, Apostolo A, Perrone-Filardi P, et al. A non invasive estimate of dead space ventilation from exercise measurements. PLoS One 2014; 9: e87395.

4 Poon C-S, Tin C, Song G. Submissive hypercapnia: why COPD patients are more prone to $\mathrm{CO}_{2}$ retention than heart failure patients. Respir Physiol Neurobiol 2015; 216: 86-93.

15 de Tarso Muller P, Barbosa GW, O’Donnell DE, et al. Cardiopulmonary and muscular interactions: potential implications for exercise (in)tolerance in symptomatic smokers without chronic obstructive pulmonary disease. Front Physiol 2019; 10: 859.

O'Donnell DE, James MD, Milne KM, et al. The pathophysiology of dyspnea and exercise intolerance in chronic obstructive pulmonary disease. Clin Chest Med 2019; 40: 343-366.

O'Donnell DE, Neder JA, Elbehairy AF. Physiological impairment in mild COPD. Respirology 2016; 21: 211-223.

O'Donnell DE, Laveneziana P, Webb K, et al. Chronic obstructive pulmonary disease: clinical integrative physiology. Clin Chest Med 2014; 35: 51-69. 
119 Woods PR, Olson TP, Frantz RP, et al. Causes of breathing inefficiency during exercise in heart failure. J Card Fail 2010; 16: 835-842.

120 Kee K, Stuart-Andrews C, Ellis MJ, et al. Increased dead space ventilation mediates reduced exercise capacity in systolic heart failure. Am J Respir Crit Care Med 2016; 193: 1292-1300.

121 Robertson HT. Gas exchange consequences of left heart failure. Compr Physiol 2011; 1: 621-634.

122 Sue DY. Excess ventilation during exercise and prognosis in chronic heart failure. Am J Respir Crit Care Med 2011; 183: 1302-1310.

123 Neder JA, Di Paolo M, O'Donnell DE, et al. On the complexities of measuring exercise "ventilatory efficiency" in obstructive lung diseases. Pediatr Pulmonol 2020; 55: 280-282.

124 Ferreira EVM, Ota-Arakaki JS, Ramos RP, et al. Optimizing the evaluation of excess exercise ventilation for prognosis assessment in pulmonary arterial hypertension. Eur J Prev Cardiol 2014; 21: 1409-1419.

125 Neder JA, Ramos RP, Ota-Arakaki JS, et al. Exercise intolerance in pulmonary arterial hypertension. The role of cardiopulmonary exercise testing. Ann Am Thorac Soc 2015; 12: 604-612.

126 Belardinelli R, Lacalaprice F, Carle F, et al. Exercise-induced myocardial ischaemia detected by cardiopulmonary exercise testing. Eur Heart J 2003; 24: 1304-1313.

127 Agostoni P, Apostolo A, Albert RK. Mechanisms of periodic breathing during exercise in patients with chronic heart failure. Chest 2008; 133: 197-203.

128 Neder JA, Rocha A, Berton DC, et al. Clinical and physiologic implications of negative cardiopulmonary interactions in coexisting chronic obstructive pulmonary disease-heart failure. Clin Chest Med 2019; 40: 421-438.

129 Neder JA, Rocha A, Alencar MCN, et al. Current challenges in managing comorbid heart failure and COPD. Expert Rev Cardiovasc Ther 2018; 16: 653-673.

130 Rocha A, Arbex FF, Sperandio PA, et al. Exercise intolerance in comorbid COPD and heart failure: the role of impaired aerobic function. Eur Respir J 2019; 53: 1802386.

131 Guazzi M, Myers J, Arena R. Cardiopulmonary exercise testing in the clinical and prognostic assessment of diastolic heart failure. J Am Coll Cardiol 2005; 46: 1883-1890.

132 Brunelli A, Charloux A, Bolliger CT, et al. The European Respiratory Society and European Society of Thoracic Surgeons clinical guidelines for evaluating fitness for radical treatment (surgery and chemoradiotherapy) in patients with lung cancer. Eur J Cardiothorac Surg 2009; 36: 181-184.

133 Brutsche MH, Spiliopoulos A, Bolliger CT, et al. Exercise capacity and extent of resection as predictors of surgical risk in lung cancer. Eur Respir J 2000; 15: 828-832.

134 Brunelli A. Ventilatory efficiency slope: an additional prognosticator after lung cancer surgery. Eur $J$ Cardiothorac Surg 2016; 50: 780-781.

135 Louvaris Z, Vogiatzis I. Physiological basis of cardiopulmonary rehabilitation in patients with lung or heart disease. Breathe 2015; 11: 120-127.

136 O'Donnell DE, Webb KA, Harle I, et al. Pharmacological management of breathlessness in COPD: recent advances and hopes for the future. Expert Rev Respir Med 2016; 10: 823-834. 